Atmos. Chem. Phys., 19, 13157-13173, 2019

https://doi.org/10.5194/acp-19-13157-2019

(C) Author(s) 2019. This work is distributed under

the Creative Commons Attribution 4.0 License.

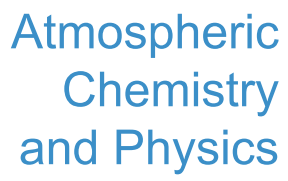

(c) (i)

\title{
Two-dimensional mineral dust radiative effect calculations from CALIPSO observations over Europe
}

\author{
Maria José Granados-Muñoz ${ }^{1,2,3}$, Michaël Sicard ${ }^{1,4}$, Nikolaos Papagiannopoulos ${ }^{1,5}$, Rubén Barragán ${ }^{1,4}$, \\ Juan Antonio Bravo-Aranda ${ }^{2,3}$, and Doina Nicolae ${ }^{6}$ \\ ${ }^{1}$ Remote Sensing Laboratory/CommSensLab, Universitat Politècnica de Catalunya, Barcelona, 08034, Spain \\ ${ }^{2}$ Andalusian Inter-University Institute for Earth System Research (IISTA-CEAMA), Avd. del Mediterráneo, 18006, Spain \\ ${ }^{3}$ Department of Applied Physics, University of Granada, Fuentenueva s/n, 18071, Spain \\ ${ }^{4}$ Ciències i Tecnologies de l'Espai - Centre de Recerca de l'Aeronàutica i de l'Espai/Institut d'Estudis Espacials de \\ Catalunya (CTE-CRAE/IEEC), Universitat Politècnica de Catalunya, Barcelona, 08034, Spain \\ ${ }^{5}$ Consiglio Nazionale delle Ricerche, Istituto di Metodologie per l'Analisi Ambientale (CNR-IMAA), Tito Scalo, 85050, Italy \\ ${ }^{6}$ National Institute of R\&D for Optoelectronics (INOE), 77125, Magurele, Romania
}

Correspondence: Maria José Granados-Muñoz (mjgranados@ugr.es)

Received: 9 May 2019 - Discussion started: 11 June 2019

Revised: 5 September 2019 - Accepted: 20 September 2019 - Published: 24 October 2019

Abstract. A demonstration study to examine the feasibility of retrieving dust radiative effects based on combined satellite data from MODIS (Moderate Resolution Imaging Spectroradiometer), CERES (Clouds and the Earth's Radiant Energy System) and CALIOP (Cloud-Aerosol Lidar with Orthogonal Polarization) lidar vertical profiles along their orbit is presented. The GAME (Global Atmospheric Model) radiative transfer model is used to estimate the shortwave and longwave dust radiative effects below the CALIPSO (CloudAerosol Lidar and Infrared Pathfinder Satellite) orbit assuming an aerosol parameterization based on the CALIOP vertical distribution at a horizontal resolution of $5 \mathrm{~km}$ and additional AERONET (Aerosol Robotic Network) data. Two study cases are analyzed: a strong long-range transport mineral dust event (aerosol optical depth, AOD, of 0.52) that originated in the Sahara Desert and reached the United Kingdom and a weaker event $(\mathrm{AOD}=0.16)$ that affected eastern Europe. The radiative fluxes obtained are first validated in terms of radiative efficiency at a single point with spacetime colocated lidar ground-based measurements from EARLINET (European Aerosol Research Lidar Network) stations below the orbit. The methodology is then applied to the full orbit. The strong dependence of the radiative effects on the aerosol load (and to a lesser extent on the surface albedo) highlights the need for accurate AOD measurements for radiative studies. The calculated dust radiative ef- fects and heating rates below the orbits are in good agreement with previous studies of mineral dust, with the radiative efficiency obtained at the surface ranging between -80.3 and $-63.0 \mathrm{~W} \mathrm{~m}^{-2}$ for lower dust concentration event and -119.1 and $-79.3 \mathrm{~W} \mathrm{~m}^{-2}$ for the strong event. Thus, results demonstrate the validity of the method presented here to retrieve 2-D accurate radiative properties with large spatial and temporal coverage.

\section{Introduction}

Mineral dust particles have a strong impact on the atmospheric radiative properties both in the short- and longwave regions of the radiation spectrum (Sokolik and Toon, 1996; Pérez et al., 2006; Balkanski et al., 2007); they also indirectly affect the cloud microphysical properties by acting as cloud condensation and ice nuclei (DeMott et al., 2003; Karydis et al., 2011). The mineral dust effect on the radiation balance of the Earth-atmosphere system is of special relevance due to its large spatial and temporal extent, being one of the most abundant aerosol particles in the atmosphere (Rosenfeld et al., 2001). Its main sources are the arid regions located mostly in northern Africa and western and central Asia. However, mineral dust is frequently transported far from its sources to Europe, America and East Asia due to the preva- 
lent global wind patterns (Morman and Plumlee, 2014). The importance of mineral dust in Europe has been recognized, and several studies have focused on the mineral dust vertical distribution using ground-based lidar systems (e.g., Ansmann et al., 2003; Mona et al., 2006; Papayannis et al., 2005, 2008; Navas-Guzmán et al., 2013).

There is a need for ground-based stations to coordinate efforts and establish adequate measurement protocols within scientific networks such as the European Aerosol Research Lidar Network (EARLINET; Pappalardo et al., 2014) in order to provide a more regional coverage, which is crucial for the analysis of mineral dust properties from the ground (Binietoglou et al., 2015; Granados-Muñoz et al., 2016; Sicard et al., 2016a, b; Barragan et al., 2017). Designated aerosol satellite sensors, even though less accurate, are still a key aspect with respect to increasing the temporal and spatial coverage for the study of aerosol properties. Sensors such as MODIS (MODerate resolution Imaging Spectroradiometer, Kaufman et al., 2002; Remer et al., 2005) and CALIOP (Cloud-Aerosol Lidar with Orthogonal Polarization; Omar et al., 2010) provide important insight to our understanding of the effects of aerosols on climate. MODIS provides reliable retrievals of spectral aerosol optical depth (AOD) with reasonably well-known uncertainties under most conditions (e.g., Kahn et al., 2010; Levy et al., 2010; Kleidman et al., 2012; Redemann et al., 2006, 2012). Conversely, CALIOP provides vertical profiles of aerosol optical properties during the day and night over a narrow swath along the satellite ground track (Winker et al., 2010). The aerosol vertical profiles provided by the CALIPSO mission globally are crucial for aerosol direct radiative effects studies, as radiative properties depend critically on the aerosol vertical distribution (Claquin et al., 1998; Zhu et al., 2007).

In general, aerosol radiative effects are usually based on data collected during intensive measurement campaigns; thus, they are generally only valid locally (Gómez-Amo et al., 2011; Perrone et al., 2012; Meloni et al., 2018; GranadosMuñoz et al., 2019). As a consequence, there is still a gap between the experimental retrieval of the aerosol radiative properties and the modeled estimations used to feed global climate models. The use of satellite measurements such as those performed by CALIPSO provide suitable spatial coverage and temporal resolution that may help to improve the determination of aerosol radiative effects at regional (Huang et al., 2009; Lemaître et al., 2010; Mallet et al., 2016; Bhawar et al., 2016) or global scales (Oikawa et al., 2013, 2018).

In the present work, we examine the feasibility of retrieving the 2-D mineral dust radiative effect along the CALIPSO flight track. Two case studies are presented here: a strong event involving mineral dust that has undergone long-range transport all the way from the Sahara Desert up to the United Kingdom which occurred in April 2011 and a weaker event affecting eastern Europe in July 2012. A parameterization of the aerosol properties is performed by combining CALIPSO information with ancillary satellite and ground-based data in order to estimate dust radiative properties in both SW (shortwave) and LW (longwave) spectra. The estimated aerosol direct radiative effects obtained with this parameterization are compared and further validated with the aerosol radiative effect calculated at two EARLINET stations located along the CALIPSO track: Granada $\left(37.2^{\circ} \mathrm{N}, 3.6^{\circ} \mathrm{W}\right)$ and Bucharest $\left(44.3^{\circ} \mathrm{N}, 26.0^{\circ} \mathrm{E}\right)$. The 1-D radiative effect is estimated using the complete set of aerosol properties necessary for the calculation and well-established methods previously validated in the literature.

The paper is structured as follows: Sect. 2 includes a brief description of the instrumentation and the datasets used; Sect. 3 is devoted to the description of the GAME radiative transfer model, and the methodology used is presented in Sect. 4; Sect. 5 presents the radiative properties of mineral dust obtained; and a short summary and concluding remarks are included in Sect. 6.

\section{Instrumentation and datasets}

\subsection{Satellite-based data}

\subsubsection{CALIPSO}

The CALIOP lidar is the main instrument aboard the CALIPSO satellite. CALIOP measures aerosol backscatter profiles at 532 and $1064 \mathrm{~nm}$, including parallel and perpendicular polarized components at $532 \mathrm{~nm}$, at high horizontal and vertical resolution. The high-resolution profiling ability coupled with depolarization measurements make CALIOP an indispensable tool for monitoring dust aerosols (Liu et al., 2008). These measurements are the basis for the Level 2 (L2) data, which include aerosol and cloud backscatter and extinction coefficients at 532 and $1064 \mathrm{~nm}$ as well as the particle depolarization ratio at $532 \mathrm{~nm}$ (Winker et al., 2009). The generation of the L2 data depends on the successful combination of three modules. First, the processing algorithm separates the atmospheric scene into distinct atmospheric layers (i.e., aerosol, cloud and surface returns; Vaughan et al., 2009, 2017). Second, for each aerosol layer the algorithm classifies the aerosol subtype (i.e., dust, polluted dust, dusty marine, clean continental, polluted continental, marine and smoke) based on a combination of information, such as the surface type, the layer integrated attenuated backscatter, the depolarization ratio at $532 \mathrm{~nm}$ and the aerosol layer height (Kim et al., 2018). Third, the aerosol backscatter $\left(\beta_{\text {aer }}\right)$ and extinction $\left(\alpha_{\text {aer }}\right)$ coefficients are retrieved assuming lidar ratio values according to the layer subtype (Young et al., 2013). CALIPSO L2 version 4 data are available from 2016 and benefit from significant advances compared with the predecessor version 3 and older releases (Kim et al., 2018; Liu et al., 2019; Tackett et al., 2018; Young et al., 2018). In this work we used CALIPSO L2 V4 data, namely the vertical 
distribution of the extinction coefficient and of the aerosol subtyping at a horizontal resolution of $5 \mathrm{~km}$.

\subsubsection{MODIS}

MODIS is a key instrument onboard the Aqua and Terra satellites that fly as part of the A-Train constellation of satellites, as well as CALIPSO. MODIS measures radiances at 36 wavelengths from 0.41 to $14 \mu \mathrm{m}$. Different algorithms are used to retrieve AOD over ocean and over land. These channels have spatial resolutions of 250 or $500 \mathrm{~m}$ and calibration of the radiances is accurate to $2 \%$ or better. Radiances are grouped into nominal $10 \mathrm{~km}$ cells containing $20 \times 20$ pixels at a $500 \mathrm{~m}$ resolution. The primary sources of uncertainty in MODIS AOD are instrument calibration errors, cloud-masking errors, incorrect assumptions regarding surface reflectance, and aerosol model selection (Remer et al., 2005; Levy et al., 2010). Retrievals are sensitive to assumptions on surface reflectance, especially over land, where reflectance is higher and more variable than over ocean, and near sun glint over ocean (Lolli et al., 2017a). These effects become more important as AOD decreases. The AOD retrieval also depends on the fine- and coarse-mode aerosol models which are used. Selection of an inappropriate model can result in systematic AOD errors. A number of validation studies listed in the following have characterized uncertainties of the MODIS AOD product. Relative to AERONET AOD measurements, Remer et al. (2005) found that 1 standard deviation of MODIS-Terra AOD fell within the expected uncertainties of $\tau= \pm 0.03 \pm 0.05 \tau$ over ocean and $\tau= \pm 0.05 \pm 0.15 \tau$ over land. In this work we use the C6 MYD04_L2 (MODIS/Aqua Aerosol 5-Min L2 Swath $10 \mathrm{~km}$ ) product which contains combined AOD at $550 \mathrm{~nm}$ over land and ocean. The MODIS level-2 atmospheric aerosol product (MYD04_L2) provides full global coverage of aerosol properties from the "Dark Target" (DT) and "Deep Blue" (DB) algorithms. The DT algorithm is applied over ocean and dark land (e.g., vegetation), whereas the DB algorithm in Collection 6 (C6) covers the entire land area including both dark and bright surfaces. Results are provided on a $10 \times 10$ pixel scale $(10 \mathrm{~km}$ at nadir). For the spectral surface albedo, the MODIS MCD43C3 Version 6 Albedo Model dataset is used (Schaaf and Wang, 2015), providing values at seven different wavelengths between 0.670 and $2.155 \mu \mathrm{m}$. This product is a $5.6 \mathrm{~km}$ daily $16 \mathrm{~d}$ product, which combines Terra and Aqua data to obtain optimized data of directional hemispherical reflectance (black sky albedo) and bi-hemispherical reflectance (white sky albedo). The MODIS BRDF/ALBEDO products have achieved stage 3 validation.

\subsubsection{CERES}

The CERES (Clouds and the Earth's Radiant Energy System; Wielicki et al., 1996) instrument, onboard the Terra and Aqua satellites alongside MODIS, is a scanning broad- band radiometer measuring filtered radiances in the SW (0.3$5 \mu \mathrm{m})$, total $(0.3-200 \mu \mathrm{m})$ and LW $(8-12 \mu \mathrm{m})$ spectral window regions. The Single Scanner Footprint (SSF) product used here contains TOA (top of the atmosphere) broadband radiance measurements along with CERES/MODIS-derived cloud and surface information (Wielicki et al., 1998) and provides data with a horizontal resolution of approximately $20 \mathrm{~km}$. The integrated emissivity between 4 and $100 \mu \mathrm{m}$ and the skin temperature are SSF Level 2 products and are used here for the retrieval of the aerosol radiative properties in the LW spectral range.

\subsection{Ground-based data}

\subsubsection{AERONET sun photometer data}

AERONET provides worldwide measurements of aerosol optical and microphysical properties. The member stations are equipped with automatic sun photometers, and more recently, with lunar photometers for nighttime operation. A detailed description of the instrument and its function can be found in Holben et al. (1998). The main product of AERONET is the AOD in distinct wavelengths from near ultraviolet $(340 \mathrm{~nm})$ to near infrared $(1064 \mathrm{~nm})$. The AOD accuracy of calibrated AERONET stations is wavelength dependent and varies from a root-mean-square error of \pm 0.012 (UV band) to a root-mean-square error of \pm 0.006 (IR band) at overhead sun (air mass =1) (Schmid et al., 1999). AERONET sun photometers also provide information about aerosol size distribution, aerosol radiative effect and aerosol shape. The retrieval of columnar particle size distribution (PSD), asymmetry factor $(g)$ and single scattering albedo (SSA), which is used here, is based on the AOD and sky radiance values using an inversion algorithm described in Dubovik and King (2000) and Dubovik et al. (2006). The uncertainty in the retrieval of SSA is \pm 0.03 for high aerosol load $\left(\mathrm{AOD}_{440}>0.4\right)$ and solar zenith angle $(\mathrm{SZA})>50^{\circ}$; while for measurements with low aerosol load $\left(\mathrm{AOD}_{440}<0.2\right)$, the retrieval accuracy of SSA drops down to $0.02-0.07$. For particles in the size range $0.1<r<7 \mu \mathrm{m}(r$ being the aerosol radius), errors in PSD retrievals are around $10 \%-35 \%$, whereas for sizes lower than $1 \mu \mathrm{m}$ and higher than $7 \mu \mathrm{m}$ retrieval errors rise up to $80 \%-100 \%$. The measurements pass multilevel quality assurance (QA): level 1 without cloud screening, level 1.5 has cloud screening but may be without final calibration. Level 2 has cloud-screened and quality-assured calibrations. Data used in the present study correspond to Version 2 Level 1.5 data.

\subsubsection{EARLINET lidar data}

EARLINET (Pappalardo et al., 2014) operates Raman lidars at the continental scale within the European region. Currently, 32 stations are actively providing aerosol extinction and/or backscatter coefficient profiles along with par- 
ticle depolarization ratio to the EARLINET database, according to EARLINET's measurement schedule (one daytime and two nighttime measurements per week). Further measurements are devoted to special events, such as volcanic eruptions, forest fires and desert dust outbreaks. The contributing stations have been performing correlative measurements since CALIPSO started its life cycle, based on a schedule established before the satellite mission, and EARLINET has been an important contributor to CALIPSO validation studies (e.g., Mamouri et al., 2009; Mona et al., 2009; Pappalardo et al., 2010; Papagiannopoulos et al., 2016). The standard instruments that the majority of the network operates are multiwavelength Raman lidars, which combine a set of three elastic and two nitrogen inelastic channels (the socalled $3+2$ configuration). This setup allows for the independent derivation of the aerosol extinction, $\alpha_{\text {aer }}$, at 355 and $532 \mathrm{~nm}$, and backscatter coefficients, $\beta_{\text {aer }}$, at 355,532 and $1064 \mathrm{~nm}$ during nighttime operation. In addition, the majority of the stations are equipped with depolarization channels, and thus provide profiles of the particle linear depolarization ratio. In this study, the EARLINET stations of Bucharest (Romania) and Granada (Spain) are used. The $\beta_{\text {aer }}(z, \lambda)$ profiles (where $z$ is the vertical height) are obtained from the EARLINET lidar systems during daytime using the KlettFernald retrieval (Fernald et al., 1972; Fernald, 1984; Klett, $1981,1985)$. The $\alpha_{\text {aer }}(z, \lambda)$ profiles are calculated by assuming a height-independent lidar ratio (LR) obtained by forcing the vertical integration of $\alpha_{\mathrm{aer}}(z, \lambda)$ to the AOD from the AERONET photometer (Landulfo et al., 2003). Uncertainty in the profiles obtained with the Klett-Fernald method is usually $20 \%$ for $\beta_{\text {aer }}(z, \lambda)$ and $25 \%-30 \%$ for $\alpha_{\text {aer }}(z, \lambda)$ profiles (Franke et al., 2001).

\subsection{Ancillary data: ERA-Interim}

The European Centre for Medium-Range Weather Forecasts (ECMWF) Interim reanalysis (ERA-Interim; Dee et al., 2011) is used for the retrieval of the meteorological profiles, namely temperature, pressure, relative humidity and ozone concentration. The dataset used has $0.125^{\circ} \times 0.125^{\circ}$ horizontal grid spacing with 29 pressure levels from 1000 to $50 \mathrm{hPa}$. The $2 \mathrm{~m}$ above ground level (a.g.l.) temperature and surface pressure data are also used. For each CALIPSO pixel along the track, we pick the nearest (by geographical distance) grid point from the ERA-Interim reanalysis data.

\section{The GAME radiative transfer model}

The dust radiative effects presented in this work are estimated with the GAME radiative transfer model. The GAME code is widely described in Dubuisson et al. $(2004,2005)$ and Sicard et al. (2014a). It is a modular radiative transfer model that allows for the calculation of upward and downward radiative fluxes at different vertical levels. Specifically, in this study we use 80 vertical levels for the SW (40 for the LW) with decreasing vertical resolution, ranging from $100 \mathrm{~m}$ to $1 \mathrm{~km}$, from the surface up to $20 \mathrm{~km}$. The solar and thermal infrared fluxes are calculated in two adjustable spectral ranges, which are fixed to $0.297-3.1 \mu \mathrm{m}$ for the SW and $4.5-40 \mu \mathrm{m}$ for the LW here, by using the discrete ordinates method (Stamnes et al., 1988). Note that the GAME code has variable spectral sampling in the SW (depending on the spectral range considered) and fixed spectral sampling (115 values) in the LW spectral range. The main input parameters required to feed the model are meteorological profiles, an aerosol model (namely characterized by AOD, SSA and $g$ ) and surface parameters such as the surface albedo or the land surface temperature (LST). For the calculations of the LW radiative properties, the spectral extinction, SSA and $g$ values are calculated from the particle size distribution using the Mie code. From the output profiles of the radiative fluxes, the mineral dust radiative effects (DRE) and heating rate (HR) profiles for both the SW and LW components are estimated. The DRE is calculated as

$\mathrm{DRE}=\left(F_{\text {down }}^{\mathrm{w}}-F_{\text {up }}^{\mathrm{w}}\right)-\left(F_{\text {down }}^{\mathrm{o}}-F_{\text {up }}^{\mathrm{o}}\right)$,

where $F^{\mathrm{w}}$ and $F^{\mathrm{o}}$ are the radiative fluxes with and without aerosols, respectively. More details on the model parameterization can be found in Granados-Muñoz et al. (2019) and detailed information on the properties used for the present study is provided in the following.

\section{Methodology}

Two different case studies are analyzed in order to demonstrate the feasibility of 2-D mineral dust radiative effect retrievals along CALIPSO flights under different dust conditions. The first case refers to a strong dust event observed on 7 April 2011 that affected western Europe and was captured by the ground-based EARLINET/AERONET Granada station. The second case refers to a weaker dust event observed over the EARLINET/AERONET Bucharest station on 4 July 2012. Henceforth we refer to the first dust event as GR and the second event as BU. An overview of both events is presented in Fig. 1, with the MODIS AOD 550 map illustrating the geographic extent of the dust plume; in addition, Fig. 1 shows the flight track of CALIPSO (black solid lines) and the location of the ground-based lidar stations (yellow pins). The identification of the source of the aerosol layers is made via an analysis of HYSPLIT (Hybrid Single Particle Lagrangian Integrated Trajectory Model; Draxler and Hess, 1998) back trajectories. The $5 \mathrm{~d}$ HYSPLIT back trajectories arriving at $2500 \mathrm{~m}$ at different points along the CALIPSO track are partly superimposed in the figure and pinpoint $\mathrm{Sa}-$ haran Desert dust as the source of the observed particles.

The mineral dust radiative property profiles are retrieved using GAME below the corresponding CALIPSO orbits. For 
(a)

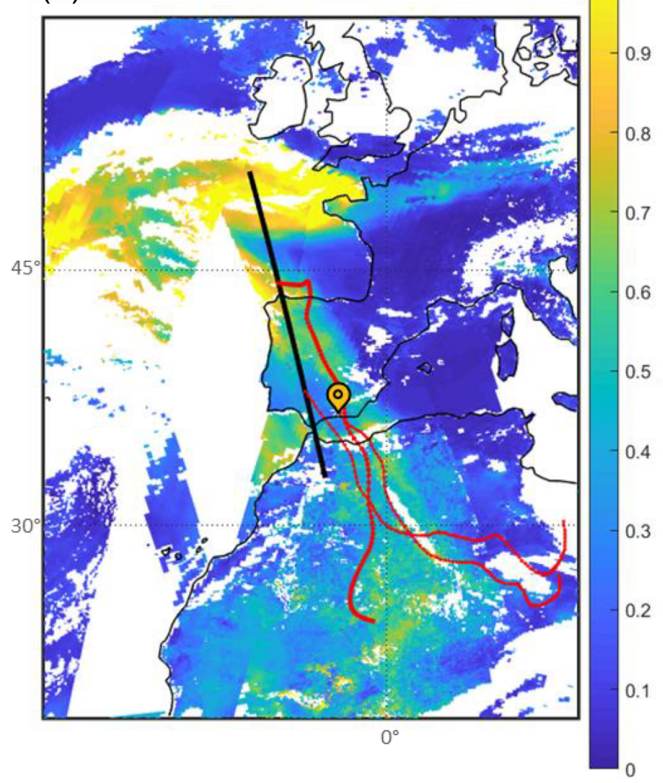

(b)

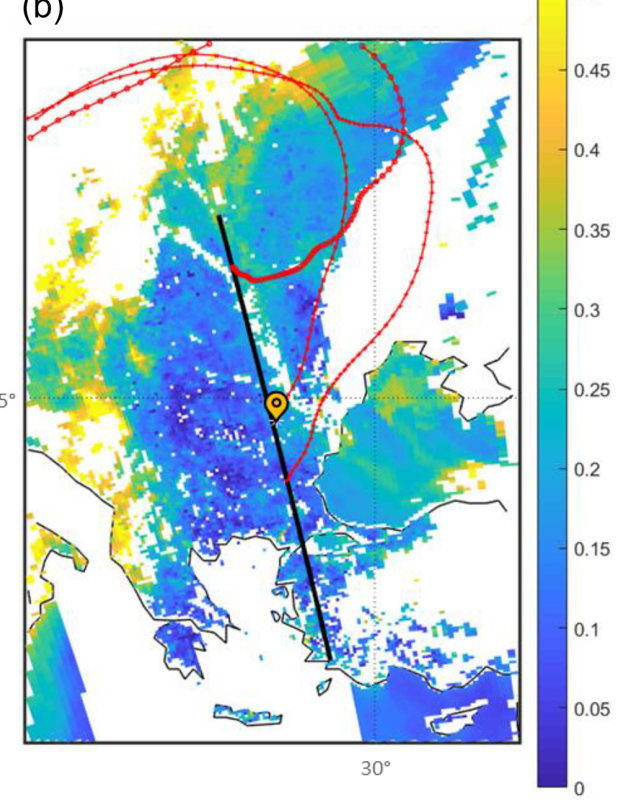

Figure 1. MODIS AOD values on 7 April 2011 (a) and 4 July 2012 (b). The yellow pins indicate the position of Granada (a) and Bucharest (b) EARLINET stations and the black thick lines show the parts of the CALIPSO tracks considered in the current study. Air mass backward trajectories arriving at $2.5 \mathrm{~km}$ are partly included, and are indicated by the red dotted lines. Note the different color scales.

both cases, the DRE profiles obtained using CALIPSO observations are intercompared with those obtained using the ground-based EARLINET lidars when CALIPSO observations and the EARLINET measurements are simultaneous and colocated. For this study, only EARLINET correlative measurements in coincidence with CALIPSO overpasses are used. The term colocated refers to the nearest CALIPSO ground track point to the corresponding ground-based location. The distance between the CALIPSO ground track and the ground-based station is $13.6 \mathrm{~km}$ for the Bucharest station and $186.7 \mathrm{~km}$ for the Granada station. The latter exceeds the $100 \mathrm{~km}$ threshold introduced by Pappalardo et al. (2010) to ensure spatial representativeness between CALIPSO and EARLINET; however, the severity of the dust event indicated similar dust characteristics for CALIPSO and EARLINET. In the case of Bucharest, the CALIPSO overpass closest to the ground-based station was at 11:28 UT and the lidar measurements are averaged between 11:27 and 12:27 UT (corresponding to an average solar zenith angle, SZA, of $25.5^{\circ}$ ). For Granada, CALIPSO overpassed the station at 13:42 UT and the lidar measurements were performed between 13:30 and 14:00 UT $\left(\mathrm{SZA} \sim 36.0^{\circ}\right)$.

The DRE estimates at the ground-based stations of Granada and Bucharest with state-of-the-art parameterizations (colocated, simultaneous lidar and sun photometer retrievals) are performed in order to validate the radiative effect estimates from CALIPSO at the location of the ground-based stations. For the analysis below the CALIPSO orbit and the analysis at the ground-based sites, two different aerosol in- put datasets are used. The first dataset (hereafter denoted as DAT1), presented in the current study, uses satellite-based extinction profiles from CALIPSO constrained by MODIS AOD, meaning that CALIPSO extinction profiles are normalized so that the integral of the extinction profile matches MODIS AOD. AERONET SSA, $g$ and PSD are also used as input in GAME in order to retrieve the DRE along the CALIPSO orbit. The total extinction profiles and AOD values considered in the study are assumed to be due to the mineral dust particles, even though some other aerosol types might be present in the mixture. The second dataset (hereafter denoted as DAT2), based on ground-based EARLINET lidar extinction profiles combined with AERONET data (namely AOD, SSA, $g$ and PSD), has been extensively validated in the literature (Sicard et al., 2014b, 2016a, b; Barragan et al., 2017; Granados-Muñoz et al., 2019) and is used here to retrieve the DRE at the Granada and Bucharest sites in order to evaluate the results obtained with DAT1.

Meteorological profiles, including vertically resolved temperature $(T)$, relative humidity $(\mathrm{RH})$ and $\mathrm{O}_{3}$ concentration, are necessary for the calculation of the radiative fluxes in GAME. They are common to both parameterizations and are obtained from the ERA-Interim database. Figure 2 shows the $T, \mathrm{RH}$ and $\mathrm{O}_{3}$ profiles obtained along the CALIPSO track for the two case studies presented here, i.e., on 7 April 2011 (GR) and 4 July 2012 (BU). Larger $T$ values and $\mathrm{O}_{3}$ concentration are observed for the BU case in general. However, $\mathrm{O}_{3}$ values larger than $0.07 \mathrm{ppmv}$ are observed in the GR orbit and are related to a stratospheric intrusion. These differences, 

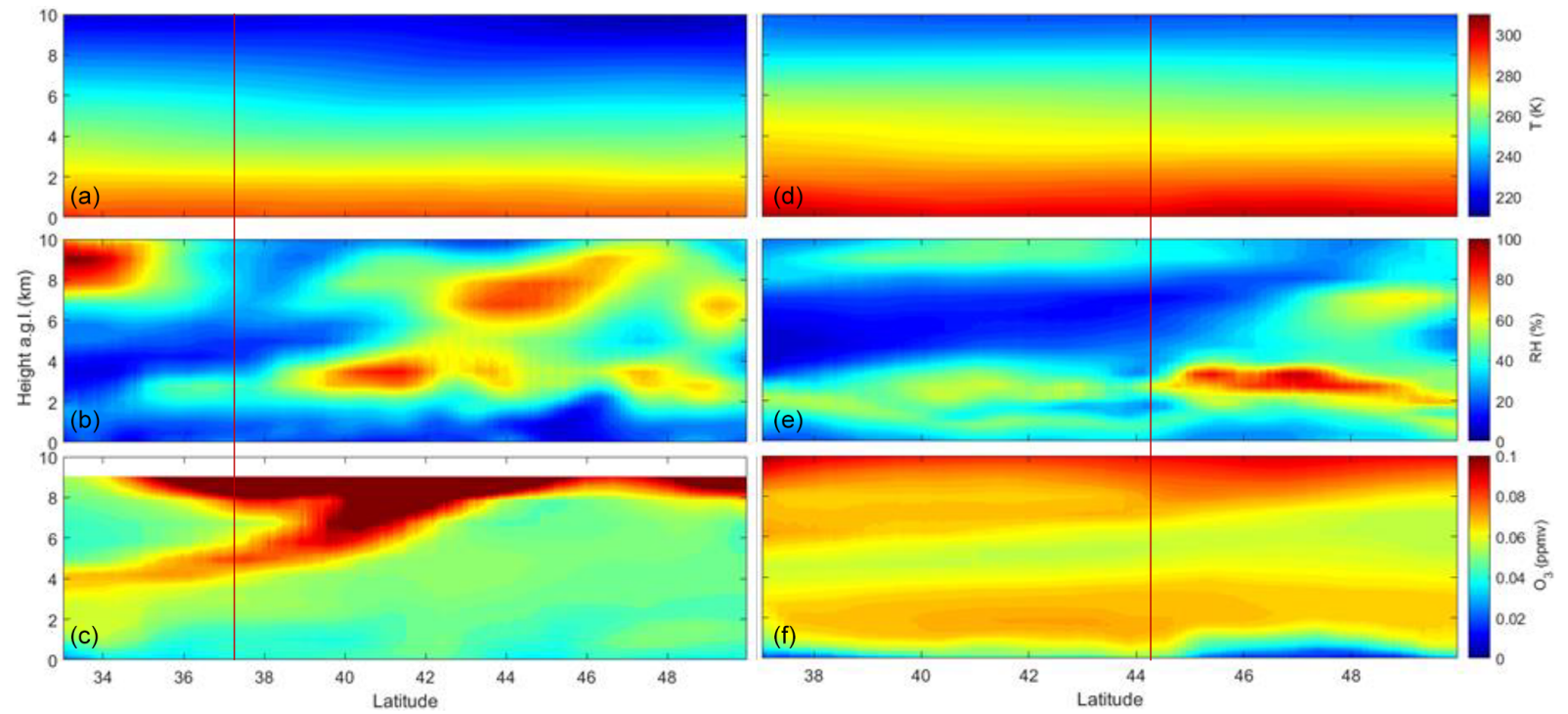

Figure 2. ERA-Interim temperature $(T ; \mathbf{a}, \mathbf{d})$, relative humidity $(\mathrm{RH} ; \mathbf{b}, \mathbf{e})$ and ozone $\left(\mathrm{O}_{3} ; \mathbf{c}, \mathbf{f}\right)$ profiles for 7 April 2011 (GR) and 4 July 2012 (BU). The vertical red lines indicate the position of the Granada $(\mathbf{a}, \mathbf{b}, \mathbf{c})$ and Bucharest $(\mathbf{d}, \mathbf{e}, \mathbf{f})$ EARLINET stations.

along with the differences in the solar position, surface and aerosol properties, lead to dissimilarity between the radiative fluxes and the DRE estimated in the GR and BU cases. The regions with high RH need to be considered in order to study possible variations in the extinction profiles due to hygroscopic growth or even cloud formation. The surface albedo data are obtained from MODIS for the SW retrievals, whilst CERES LW surface emissivity and skin temperature (or land surface temperature, hereafter denoted as LST) are used in the retrieval of the $\mathrm{LW}$ radiative properties.

\subsection{Aerosol characterization based on satellite measurements}

Mineral dust radiative properties are obtained along the CALIPSO track for those profiles where mineral dust is detected, according to the aerosol typing provided by CALIPSO. For the parameterization of GAME retrievals along the CALIPSO track, the so-called DAT1, we make use of the $\alpha_{\text {aer }}$ profiles provided by CALIPSO, constrained by colocated MODIS AOD values. Although CALIPSO provides AOD information by integrating the $\alpha_{\text {aer }}$ profiles, these data are usually affected by large uncertainties (e.g., Wandinger et al., 2010; Rogers et al., 2014). Here, we chose to constrain the CALIPSO profiles with MODIS AOD that has been extensively validated (Levy et al., 2005; Remer et al., 2012; Gupta et al., 2018). Furthermore, the DRE estimations are highly dependent on the AOD; thus, by using the well-established MODIS data, we aim to improve the accuracy of the retrievals. Simultaneous MODIS SW surface albedo data are also used to retrieve the aerosol radiative effect profiles. Figure 3 shows the curtain plot of the MODISconstrained $\alpha_{\text {aer }}$ profiles obtained along the CALIPSO flight track and the averaged profiles for both the GR and BU dust events. MODIS surface albedo values at $675 \mathrm{~nm}$ and AOD at $550 \mathrm{~nm}$ are also depicted (black and red dots, respectively). The $\alpha_{\text {aer }}$ is much larger for GR, almost twice as large as in $\mathrm{BU}$, and the mineral dust layer reaches much higher altitudes $(5 \mathrm{~km}$ a.g.l., whereas in BU the dust is constrained below $4 \mathrm{~km}$ ). On the averaged profiles, we can see that the maximum is found between 1 and $5 \mathrm{~km}$ for GR, whereas the profile is quite homogeneous below $4 \mathrm{~km}$ for the BU event. In both cases, the AOD generally increases with latitude, with larger values and much more variability in GR. For the surface albedo, there is a strong decrease in GR above $44^{\circ} \mathrm{N}$, where the surface changes from land to sea (see also Fig. 1).

Assuming that the mineral dust optical and microphysical properties are homogeneous for each one of the events analyzed here, the spectral values of the SSA, $g$ and the PSD are taken from the AERONET Level 1.5 inversions at Granada and Bucharest and assumed to be constant along the track. Unfortunately, Level 2.0 data were not available at the time of the measurements. The assumption of constant SSA, $g$ and PSD values is not exempt of uncertainty, but it is expected to be almost negligible, as the main driver of the DRE is the AOD (e.g., Granados-Muñoz et al., 2019). Figure 4 shows the AERONET data used as input in GAME including the SSA (Fig. 4a), $g$ (Fig. 4b) and PSD (Fig. 4c). The SSA values and their spectral dependence over Granada and Bucharest are typical of mineral dust particles, i.e., an increasing SSA with wavelength, even though the large SSA values at $440 \mathrm{~nm}$ for Bucharest indicate mixing with anthropogenic pollution from the city in the lower layers near the surface. Although the asymmetry factor has a different behavior at both stations, it is rather spectrally independent (variations lower than 0.04 

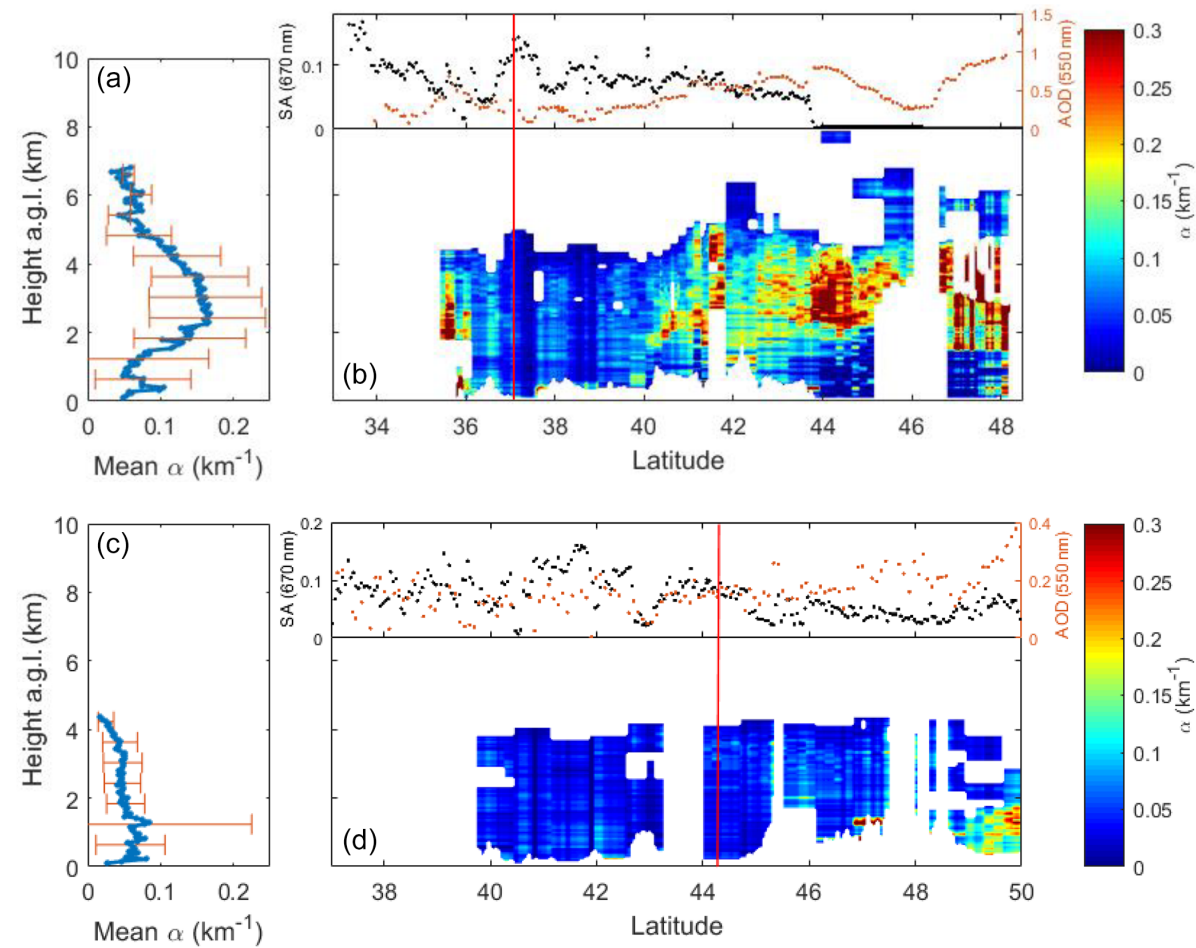

Figure 3. Aerosol extinction at $532 \mathrm{~m}$ as provided by CALIPSO and constrained by MODIS AOD on 7 April 2011 (a, b) and 4 July 2012 (c, d) as well as the corresponding averaged profiles for the considered part of the track (a, c). The error bars are the standard deviation. The red vertical lines represent the locations of the Granada $(\mathbf{a}, \mathbf{b})$ and Bucharest $(\mathbf{c}, \mathbf{d})$ stations. MODIS AOD $550 \mathrm{~nm}$ (orange dots) and surface albedo at $670 \mathrm{~nm}$ (black dots) along the track are also depicted in the top part of the curtain plots.

(a)

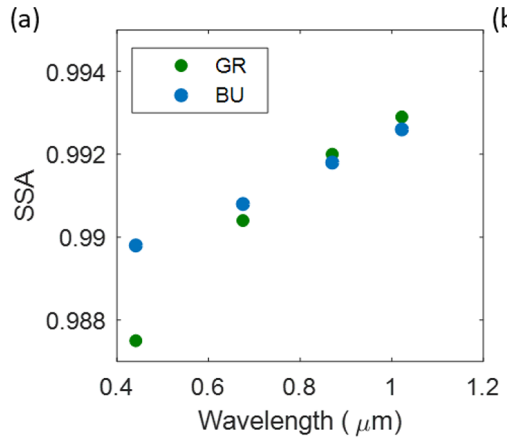

(b)

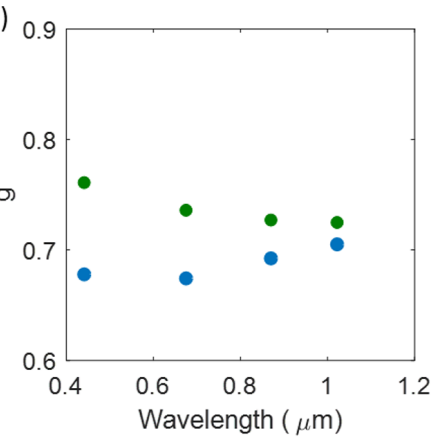

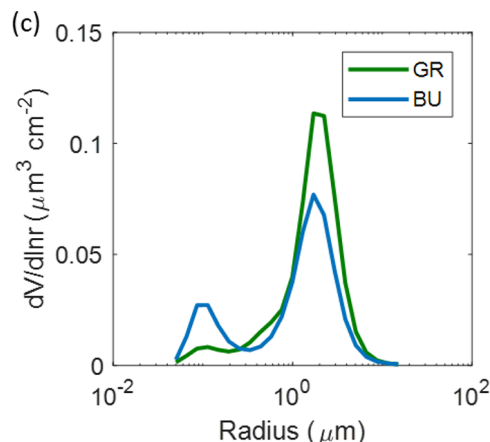

Figure 4. AERONET Level 1.5 retrieved (a) single scattering albedo (SSA), (b) asymmetry factor $(g)$ and (c) particle size distribution for the Granada (green) and Bucharest (blue) stations.

between 440 and $1020 \mathrm{~nm}$ ) in both of them which again reflects the typical signature of mineral dust. For the meteorological profiles, data are obtained from the ERA-Interim reanalysis (see Fig. 2). LW surface emissivity and LST are provided by CERES.

\subsection{Aerosol characterization based on ground-based measurements}

For DAT2, the $\alpha_{\text {aer }}$ profiles containing information about the aerosol vertical distribution are obtained from the ground- based EARLINET lidar systems constrained by the sun photometer AOD provided by AERONET (Fig. 5 and Table 1). The incomplete overlap for the EARLINET systems has not been corrected here; the $\alpha_{\text {aer }}$ values in the affected region are assumed to be constant and closest to the surface valid value in the profile. The values of the SSA, $g$ and the PSD are provided by the AERONET Level 1.5 inversions shown in Fig. 4. The surface albedo at the Granada and Bucharest sites is obtained from MODIS data, whereas the longwave emissivity and the LST from CERES are used. Meteorological profiles from ERA-Interim are retrieved for the pixels 


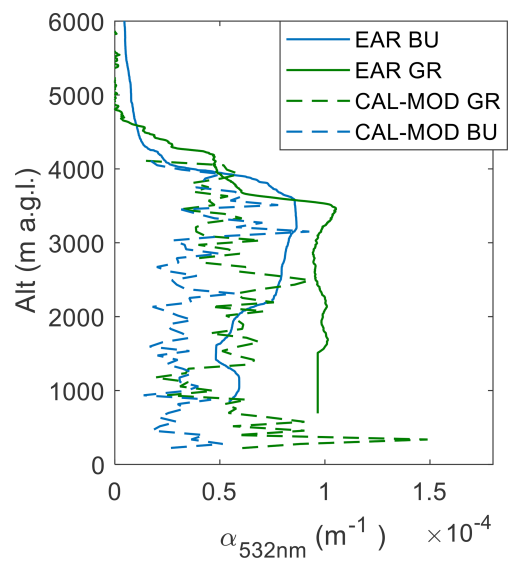

Figure 5. AOD-constrained aerosol extinction profiles retrieved with the ground-based EARLINET lidars (solid line) and CALIPSO (dashed line) for the Granada (green) and Bucharest (blue) stations.

Table 1. AERONET and MODIS retrieved AOD at $550 \mathrm{~nm}$; the Angstrom exponent between 440 and $870 \mathrm{~nm}, \mathrm{AE}(440-870 \mathrm{~nm})$, retrieved by AERONET; and surface albedo (SA) at $470 \mathrm{~nm}$ obtained from MODIS data above the Granada and Bucharest stations.

\begin{tabular}{rrrr}
\hline & $\begin{array}{r}\text { AOD 550 } \\
\text { (AER/MODIS) }\end{array}$ & $\begin{array}{r}\text { AE(440-870 nm) } \\
\text { AERONET }\end{array}$ & $\begin{array}{r}\text { SA(470 nm) } \\
\text { MODIS }\end{array}$ \\
\hline GR & $0.34 / 0.22$ & 0.27 & 0.05 \\
BU & $0.22 / 0.14$ & 0.75 & 0.048 \\
\hline
\end{tabular}

containing the Granada and Bucharest stations. Simultaneous and colocated CALIPSO $\alpha_{\text {aer }}$ profiles constrained by MODIS AOD are also depicted in Fig. 5. Very similar vertical structures are detected by the ground-based lidar and CALIPSO, even though CALIPSO profiles are expectedly much noisier. As for the $\alpha_{\text {aer }}$ values, the satellite profiles slightly underestimate the ground-based measurements. This is directly related to the lower MODIS AOD values compared with AERONET (Table 1). Differences of 0.12 and 0.08 are observed at Granada and Bucharest, respectively, between AERONET and MODIS nearest pixel AODs, which are larger than the combined uncertainty. These differences in the aerosol load are expected due to the distance between the satellite overpasses and the ground-based station, the time difference between the AERONET and MODIS measurements ( 5 min for GR and 20 min for BU), and the different horizontal resolution $(10 \mathrm{~km}$ for MODIS vs. a point value measured by AERONET). As the DRE is highly dependent on the AOD values, the comparison of the radiative properties at the stations between the retrieval obtained using the EARLINET lidars and the one using CALIPSO is made in terms of the radiative efficiency (RE) to avoid this dependence. The RE is defined here as the ratio between the DRE and the $\mathrm{AOD}_{550}$.

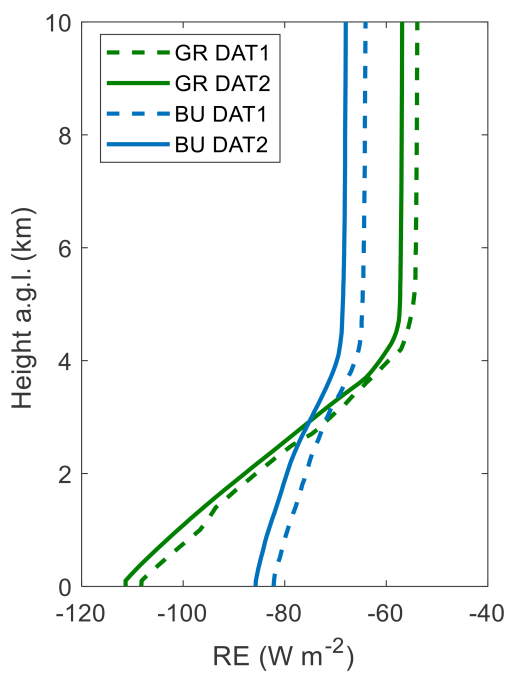

Figure 6. Profiles of the radiative efficiency (RE) obtained using CALIPSO (DAT1) and the ground-based EARLINET lidar (DAT2) extinction profiles on 4 April 2011 above Granada (GR) and on 7 July 2012 above Bucharest (BU).

A summary of the data used for the two aerosol input parameterizations (DAT1 and DAT2) can be found in Table 2. The parameters that are variable along the satellite track are indicated using italic font.

\section{Mineral dust radiative properties}

\subsection{Radiative properties profiles at the EARLINET sites of Granada and Bucharest}

The aerosol RE profiles obtained with GAME at the EARLINET stations of Granada and Bucharest are presented in Fig. 6. The dashed lines represent the profiles retrieved using the DAT1 parameterization based on CALIPSO $\alpha_{\text {aer }}$ profiles constrained by simultaneous MODIS AOD retrievals and colocated with the EARLINET-retrieved $\alpha_{\text {aer }}$ profiles used in DAT2, represented by the solid lines.

In the case of the dust outbreak affecting Granada in 2011, we observe that the RE at the surface is much larger (in absolute values), whereas at the TOA lower values are obtained. A similar behavior is observed for Bucharest, even though differences between the RE at the BOA (bottom of the atmosphere) and TOA are smaller. A quite different impact on the RE both at the BOA and the TOA is observed for the two events. Differences in the dust properties and the different SZAs affect the radiative impact of the aerosol particles, producing a stronger effect at the BOA for Granada and at the TOA for Bucharest. Altogether, we obtain a cooling effect both at the BOA and the TOA, which is in agreement with previous studies of mineral dust radiative effects ( $\mathrm{Di}$ Biagio et al., 2009; Gómez-Amo et al., 2011; Meloni et al., 2015). Small differences (lower than $3 \mathrm{~W} \mathrm{~m}^{-2}$ ) are obtained 
Table 2. Input parameters used for GAME retrievals of the DRE for parameterizations 1 (DAT1) and 2 (DAT2). Those parameters which are variable along the track are marked using italic font (CAL refers to CALIPSO; AER refers to AERONET; EAR refers to EARLINET; ERA-Int refers to ERA-Interim).

\begin{tabular}{lllllllll}
\hline & $\alpha_{\mathrm{aer}}(z)$ & $\operatorname{AOD}(\lambda)$ & $\mathrm{SSA}(\lambda)$ & $g(\lambda)$ & $\mathrm{SA}(\lambda)(\mathrm{SW} / \mathrm{LW})$ & $\mathrm{PSD}$ & $\operatorname{Met}(z)$ & $\mathrm{LST}$ \\
\hline DAT1 & CAL & MODIS & \multirow{2}{*}{ AER } & \multirow{2}{*}{ AER } & MODIS/CERES & \multirow{2}{*}{ AER } & ERA-Int & CERES \\
DAT2 & EAR & AER & & & MODIS/CERES & & ERA-Int & CERES
\end{tabular}

between the two parameterizations. Nonetheless, these differences are not significant as they are lower than the uncertainty related to the uncertainties in the input profiles, which can reach $25 \%$ according to estimations presented in Granados-Muñoz et al. (2019). Thus, despite the larger noise in the CALIPSO signals compared with EARLINET, the results indicate that the vertical distribution of the mineral dust provided by CALIPSO combined with MODIS AOD provide similar results to those obtained by ground-based stations. The methodology used here for the ground-based stations has already been extensively validated (Sicard et al., 2014b, 2016a, b; Barragan et al., 2017; Granados-Muñoz et al., 2019) and the extension of this methodology for the CALIPSO space mission allows us to greatly increase spatial and temporal coverage.

\subsection{DRE below CALIPSO overpass}

Figure 7 shows the resulting $\mathrm{DRE}_{\mathrm{SW}}, \mathrm{DRE}_{\mathrm{LW}}$ and the $\mathrm{DRE}_{\mathrm{LW}} / \mathrm{DRE}_{\mathrm{SW}}$ ratio profiles obtained from the GAME simulations for GR and BU dust events. Variations along the satellite tracks are mostly driven by changes in the $\alpha_{\text {aer }}$ profiles, with larger absolute values of the DRE observed in regions with higher aerosol load. The high standard deviation and range indicate a large variability of the DRE along the track, with those regions where the AOD is minimum having an almost negligible radiative effect $\left(-8.6\right.$ and $-0.2 \mathrm{~W} \mathrm{~m}^{-2}$ at the BOA at GR and BU, respectively). Values as large as $-169.8 \mathrm{~W} \mathrm{~m}^{-2}$ at the BOA for the $\mathrm{SW}$ are obtained for GR, whereas for BU they reach only $-38.0 \mathrm{~W} \mathrm{~m}^{-2}$. For the $\mathrm{LW}$, the DRE ranges between 1.0 and $20.0 \mathrm{~W} \mathrm{~m}^{-2}$ at the BOA in GR and between 0.0 and $4.0 \mathrm{~W} \mathrm{~m}^{-2}$ in BU. The opposite effect observed for the LW, where the DRE has a positive sign, counterweights the cooling in the SW range, and averaged net DRE values at the BOA and TOA, respectively, are -52.9 and $-33.5 \mathrm{~W} \mathrm{~m}^{-2}$ for GR and -12.4 and $-10.5 \mathrm{~W} \mathrm{~m}^{-2}$ for $\mathrm{BU}$, which translates into a decrease of the net DRE ranging between $10 \%$ and $20 \%$ compared with the SW values. The profiles obtained at the location of the ground-based stations are also included in Fig. 7. In the case of GR, these profiles correspond to a very low aerosol load compared with the rest of the track and the DRE is close to the minimum, whereas for the case of BU the DRE is close to the averaged values along the track. For the $\mathrm{DRE}_{\mathrm{LW}} / \mathrm{DRE}_{\mathrm{SW}}$ ratio similar values are obtained on average for both cases, with the averaged profiles ranging between $10 \%$ and $15 \%$ and maximum values always below $25 \%$, indicating similar relative LW-to-SW properties of the two events despite the differences in the optical and microphysical properties observed between the events. For GR, a strong increase in the DRE, especially in the SW, is observed for latitudes above $44^{\circ} \mathrm{N}$, where the shift from land to ocean occurs. Above this latitude, there is a strong decrease of the SW surface albedo (Fig. 4), whereas for the LW, the surface albedo increases slightly from 0.013 to 0.018 (not shown). Actually, the average $\mathrm{DRE}_{\mathrm{SW}}\left(\mathrm{DRE}_{\mathrm{LW}}\right)$ at the $\mathrm{BOA}$ is $-91.0 \mathrm{~W} \mathrm{~m}^{-2}$ $\left(11.6 \mathrm{~W} \mathrm{~m}^{-2}\right)$ for the ocean portion and it almost halved for the land portion, being $-46.9 \mathrm{~W} \mathrm{~m}^{-2}\left(7.7 \mathrm{~W} \mathrm{~m}^{-2}\right)$. The influence of the surface albedo is more important for the SW than for the $\mathrm{LW}$; thus, lower $\mathrm{DRE}_{\mathrm{LW}} / \mathrm{DRE}_{\mathrm{SW}}$ ratio values are obtained over $44^{\circ} \mathrm{N}$.

The strong dependence of the DRE on the $\alpha_{\text {aer }}$ values and, thus, on the aerosol load is also evident in the strong negative correlation observed between the DRE at the surface and the AOD. Figure 8 shows the MODIS AOD at $550 \mathrm{~nm}$ and the DRE values at the surface along the CALIPSO track for GR and BU. For both cases a general increase of the AOD $_{550}$ is observed as the latitude increases (see also Fig. 1), even though the values for GR are more variable. The increase in $\mathrm{AOD}_{550}$ is very well correlated with the increase (in absolute value) of the total DRE at the BOA. Correlation coefficients of -0.98 for Granada and -0.70 for Bucharest are obtained. This strong dependence of the DRE on the AOD is already well-documented (Prasad et al., 2007; Sicard et al., 2014a; Lolli et al., 2017b, 2018; Meloni et al., 2018) and, consequently, by using the RE we avoid this dependency.

The RE values are obtained along the CALIPSO tracks (Fig. 9). On average, the RE at the BOA is much larger in absolute terms for GR. The values obtained range between -80.3 and $-63.0 \mathrm{~W} \mathrm{~m}^{-2}$ for $\mathrm{BU}$ and -119.1 and $-79.3 \mathrm{~W} \mathrm{~m}^{-2}$ for GR. For the TOA, similar average values are obtained at both stations, ranging between -79.5 and $-36.8 \mathrm{~W} \mathrm{~m}^{-2}$ at $\mathrm{GR}$ and -69.4 and $43.3 \mathrm{~W} \mathrm{~m}^{-2}$ at BU. The GR case presents similar values to those observed in previous studies (Gómez-Amo et al., 2011; Peris-Ferrús et al., 2017), whereas the retrieved RE for BU at the BOA is usually lower, even though it is necessary to consider the differences in SZA. The differences between the RE observed at GR and BU are related to the different aerosol properties observed in the AERONET data, but mostly related to the different SZAs and the surface albedo (Gómez-Amo et al., 
GR
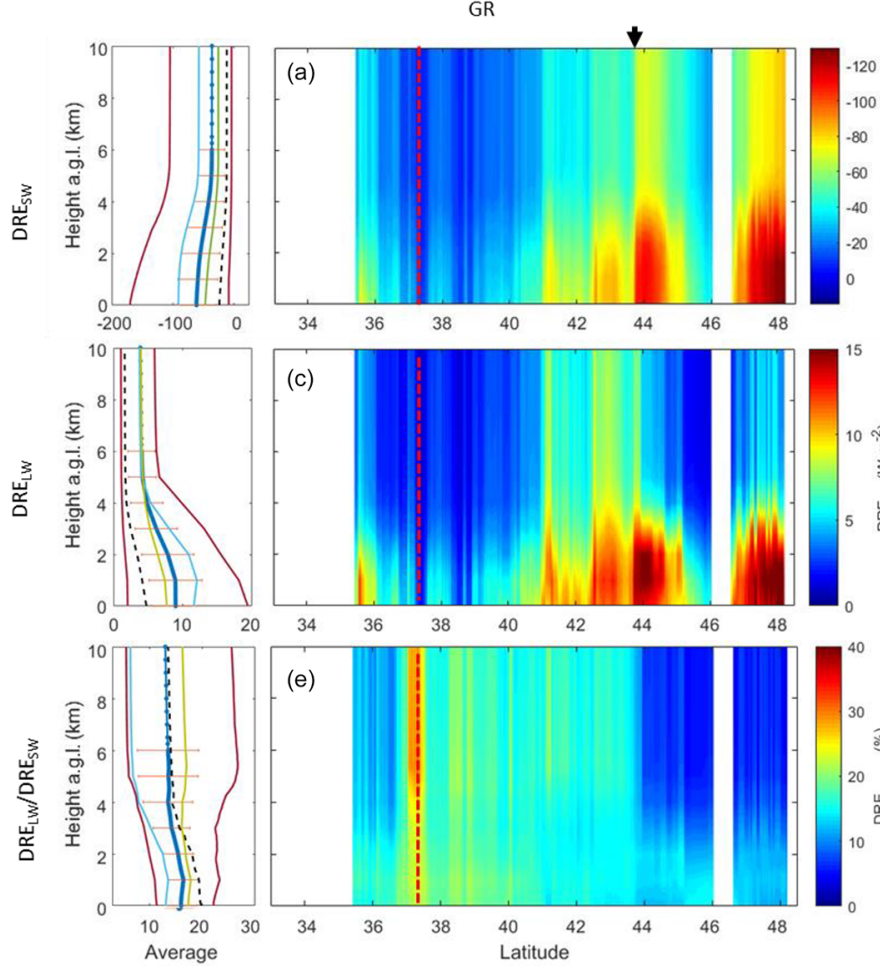

(e)
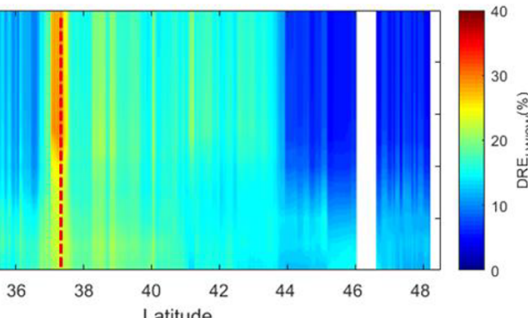
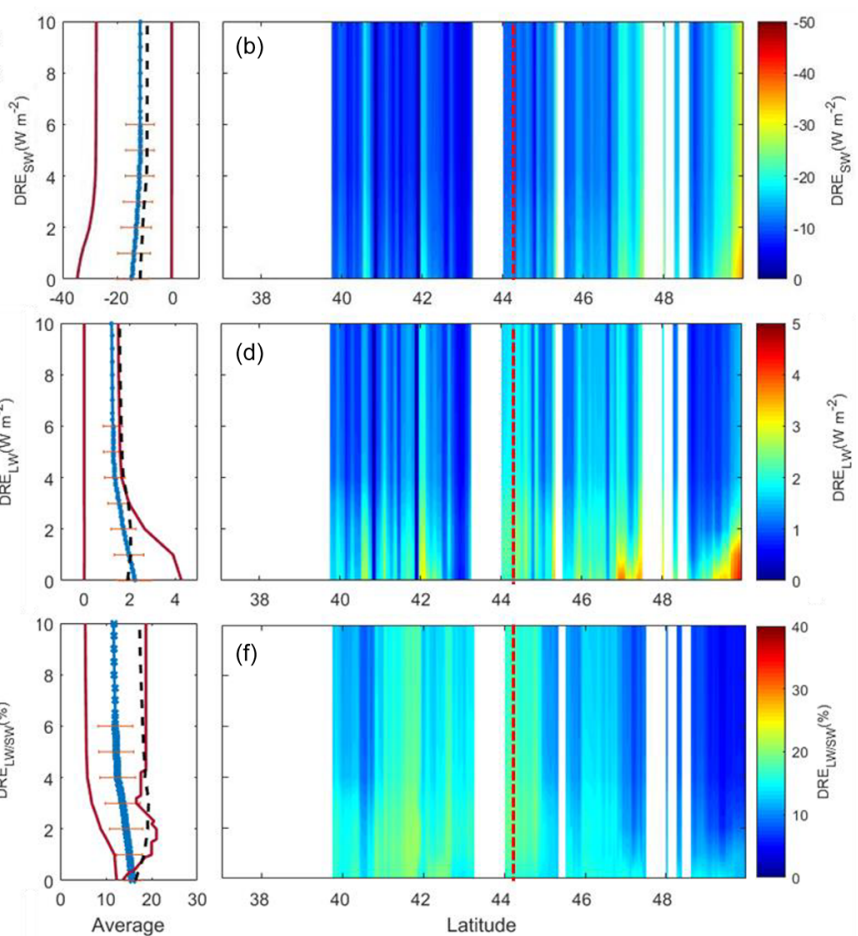

Figure 7. Averaged profiles (blue lines) showing their standard deviation (orange error bars), and curtain plots of the DRE $\mathrm{SW}$ (a, b), $\mathrm{DRE}_{\mathrm{LW}}(\mathbf{c}, \mathbf{d})$ and $\mathrm{DRE}_{\mathrm{SW}} / \mathrm{DRE}_{\mathrm{LW}}(\mathbf{e}, \mathbf{f})$ profiles obtained along the CALIPSO track for GR (a, c, e) and BU (b, d, f). Note the different scales. The red solid lines show the profiles corresponding to minimum and maximum, AOD and the dashed black lines represents the profiles above the ground-based sites. For GR, the green and light blue lines show the averaged profiles for land and ocean, respectively. The dashed red vertical lines represent the location of the EARLINET stations. The black arrow above panel (a) indicates the latitude where the surface shifts from land to ocean.
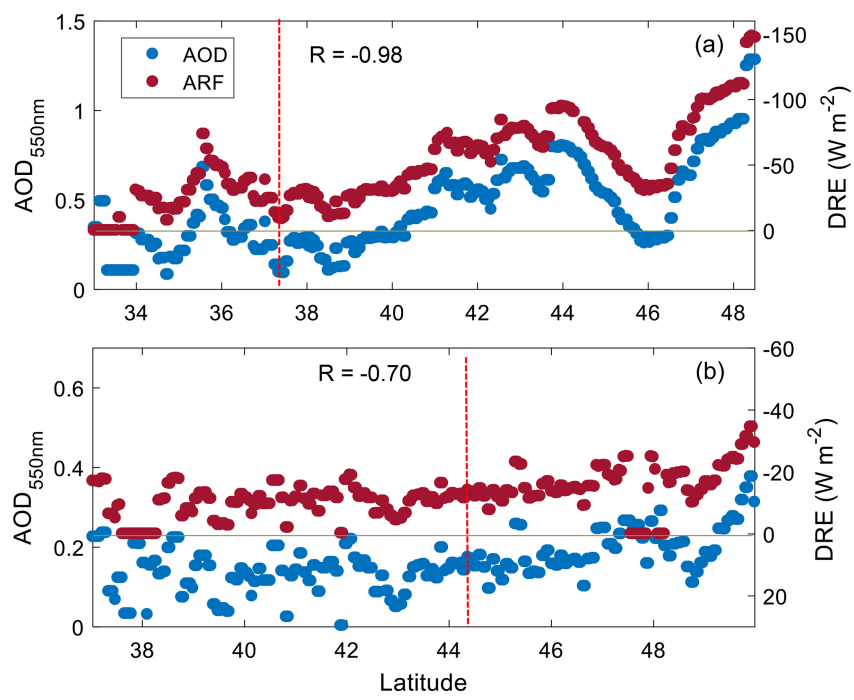

Figure 8. $\mathrm{AOD}_{550}$ from MODIS (blue dots) and $\mathrm{DRE}_{\mathrm{BOA}}$ from GAME (red dots) along the CALIPSO track for GR (a) and BU (b). The dashed red vertical lines represent the location of the EARLINET stations. The correlation coefficient between the DRE $\mathrm{BOA}_{\mathrm{B}}$ and the $\mathrm{AOD}_{550}, R$, is reported in each plot.
2011). A quite strong increase is observed in the GR track for latitudes higher than $44^{\circ} \mathrm{N}$, in coincidence with the decrease of the surface albedo and in agreement with what we observed for the DRE. Average values above ocean are equal to $-119.8 \mathrm{~W} \mathrm{~m}^{-2}$ at the BOA and $-81.7 \mathrm{~W} \mathrm{~m}^{-2}$ at the TOA, whereas over land the RE is much weaker due to the surface albedo, with a $\mathrm{RE}$ of $-96.0 \mathrm{~W} \mathrm{~m}^{-2}$ at the $\mathrm{BOA}$ and $-52.3 \mathrm{~W} \mathrm{~m}^{-2}$ at the TOA.

The track-averaged values obtained at the BOA and TOA are summarized in Table 3. The DRE (in absolute terms) is much larger at GR for both the SW and LW components. For this case, the aerosol load is much higher, as indicated by the averaged $\mathrm{AOD}_{550}$ values along the track $(0.52$ for GR vs. 0.16 for $\mathrm{BU}$ ). In the case of the SW, a cooling of the surface is observed in both cases, with the averaged $\mathrm{DRE}_{\mathrm{BOA}}=-66.7 \pm 35.7$ and $-14.6 \pm 5.2 \mathrm{~W} \mathrm{~m}^{-2}$ for $\mathrm{GR}$ and $\mathrm{BU}$, respectively. At the TOA, the DRE obtained is equal to $-39.7 \pm 23.6$ and $-11.7 \pm 5.2 \mathrm{~W} \mathrm{~m}^{-2}$ for GR and BU, respectively. For the LW fraction, positive values are obtained at both the BOA and the TOA, indicating a heating that partly counterbalances the cooling of the SW spectral range. In general, the LW DRE fraction represents $10 \%-15 \%$ of the SW, with larger values near the surface. Overall, this fraction is 

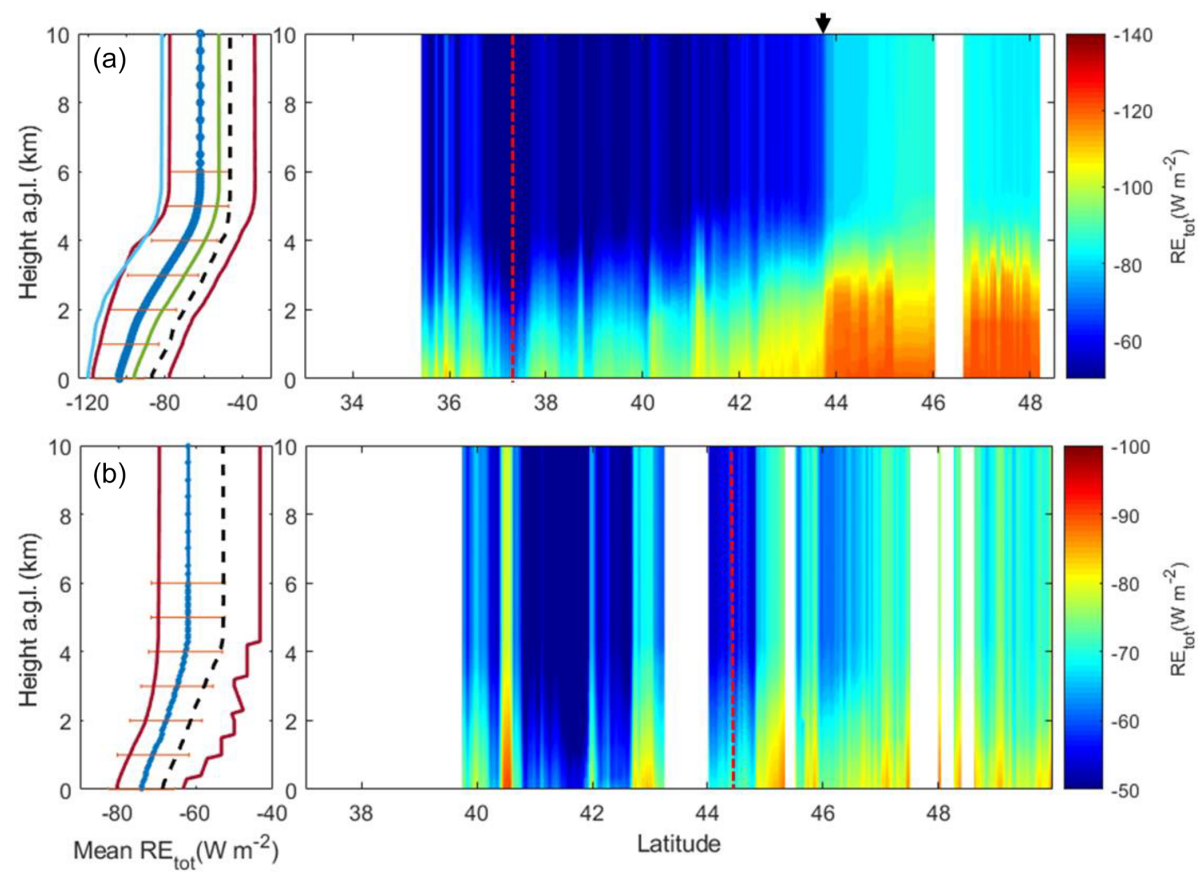

Figure 9. Averaged profiles (blue lines) showing their standard deviation (orange error bars), and curtain plots of the RE along the CALIPSO track for the GR (a) and BU (b) cases. The dashed red vertical lines represent the location of the EARLINET stations. The red solid lines show the profiles corresponding to minimum and maximum AOD, and the dashed black lines represents the profiles above the ground-based sites. For GR, the green and light blue lines show the averaged profiles for land and ocean, respectively. The black arrow above panel (a) indicates the latitude where the surface shifts from land to ocean.

Table 3. DRE, RE and AOD average values \pm standard deviation along the CALIPSO tracks for GR and BU.

\begin{tabular}{|c|c|c|c|c|}
\hline & \multicolumn{2}{|c|}{ GR } & \multicolumn{2}{|c|}{$\mathrm{BU}$} \\
\hline & BOA & TOA & BOA & TOA \\
\hline $\mathrm{DRE}_{\mathrm{SW}}\left(\mathrm{W} \mathrm{m}^{-2}\right)$ & $-66.7 \pm 35.7$ & $-39.7 \pm 23.6$ & $-14.6 \pm 6.3$ & $-11.7 \pm 5.2$ \\
\hline $\operatorname{DRE}_{L W}\left(\mathrm{~W} \mathrm{~m}^{-2}\right)$ & $9.5 \pm 3.9$ & $3.9 \pm 1.8$ & $2.2 \pm 0.8$ & $1.2 \pm 0.4$ \\
\hline $\operatorname{DRE}\left(\mathrm{W} \mathrm{m}^{-2}\right)$ & $-52.9 \pm 36.3$ & $-33.5 \pm 25.4$ & $-12.4 \pm 5.5$ & $-10.5 \pm 5.0$ \\
\hline $\mathrm{DRE}_{\mathrm{SW}} / \mathrm{DRE}_{\mathrm{LW}}(\%)$ & $16.0 \pm 2.9$ & $13 \pm 5.6$ & $15.8 \pm 2.1$ & $11.7 \pm 3.7$ \\
\hline $\operatorname{RE}\left(\mathrm{W} \mathrm{m}^{-2}\right)$ & $-104.9 \pm 13.4$ & $-63.6 \pm 15.9$ & $-74.1 \pm 87$ & $-61.9 \pm 9.5$ \\
\hline $\mathrm{AOD}_{550}$ & \multicolumn{2}{|c|}{$0.52 \pm 0.25$} & \multicolumn{2}{|c|}{$0.16 \pm 0.06$} \\
\hline
\end{tabular}

in agreement with the values obtained in previous studies for the European region ranging between $9 \%$ and $26 \%$ (Perrone and Bergamo, 2011; di Sarra et al., 2011; Sicard et al., 2014b, a; Lolli et al., 2018; Meloni et al., 2018).

The SW vertical distribution of the HR is highly correlated with the $\alpha_{\text {aer }}$ values as well, when comparing Figs. 3 and 10, where larger HR values are observed in those layers with higher extinction. On average, we can see that the HR reaches a maximum in the layer between 1 and $5 \mathrm{~km}$ for the GR case, whereas it is very homogeneous below $4 \mathrm{~km}$ in the BU case and is in agreement with the $\alpha_{\text {aer }}$ profiles in Fig. 3. The HR values are much lower in the BU case, as the aerosol load is low compared with the GR event. The averaged profiles obtained at GR reach up to $0.72 \mathrm{~K} \mathrm{~d}^{-1}$, whereas at $\mathrm{BU}$ they are lower by a factor of 10 . The maximum value observed for the BU case is $0.25 \mathrm{~K} \mathrm{~d}^{-1}$ for altitudes around $1.5 \mathrm{~km}$ at high latitudes, whereas for GR, values as large as $3.7 \mathrm{~K} \mathrm{~d}^{-1}$ are found at altitudes between 3.5 and $4 \mathrm{~km}$ from $44^{\circ} \mathrm{N}$ onwards. For the LW, the mineral dust effect is much lower and shows the opposite behavior to that observed for the SW, as it occurs with the DRE values. In this case, the cooling rate values are as low as $-0.18 \mathrm{~K} \mathrm{~d}^{-1}$ for GR and are $-0.02 \mathrm{~K} \mathrm{~d}^{-1}$ for BU on average. The maximum cooling rates are $-0.52 \mathrm{Kd}^{-1}$ for $\mathrm{GR}$ and $-0.35 \mathrm{Kd}^{-1}$ for BU. A slight heating can be observed near the surface, below the dust layers, especially in the GR event in the last part of the track (latitude $>42^{\circ} \mathrm{N}$ ). This result (negative LW HR values in the dust layer and positive below it) has been reported by 

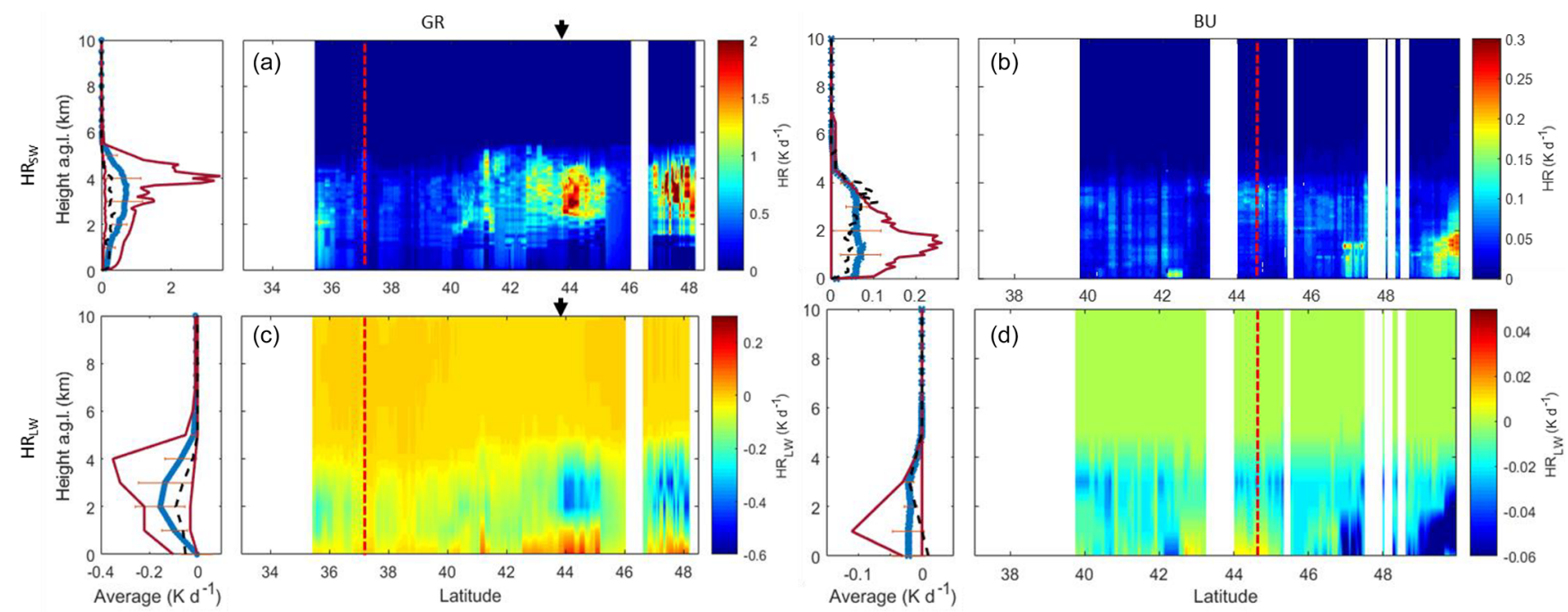

Figure 10. Averaged profiles (blue lines) showing their standard deviation (orange error bars), and curtain plots of the HR profiles along the CALIPSO track for the SW (a, b) and LW $(\mathbf{c}, \mathbf{d})$ for the GR $(\mathbf{a}, \mathbf{c})$ and BU $(\mathbf{b}, \mathbf{d})$ cases. The dashed red vertical lines represent the location of the EARLINET stations. The red solid lines show the profiles corresponding to minimum and maximum AOD, and the dashed black lines represents the profiles above the ground-based sites. For GR, the black arrow above panel (a) indicates the latitude where the surface shifts from land to ocean.

Huang et al. (2009) and Wang et al. (2013), among others, and reflects the heating of the surface layers due to the absorption of the LW radiation emitted by the dust layer above.

The cooling of the dust layers in the LW slightly counterbalances the heating due to the absorption of SW radiation. Net HR values on the averaged profiles reach a maximum of 0.63 and $0.05 \mathrm{~K} \mathrm{~d}^{-1}$ for GR and BU, respectively, which are 0.09 and $0.02 \mathrm{~K} \mathrm{~d}^{-1}$ lower than the values in the SW (a decrease of $7 \%$ and $20 \%$, respectively). The averaged HR LWto-SW ratios are similar in both cases: $25 \%$ for GR and $28 \%$ for BU. In general terms, the HR values and the ratios obtained here are in quite good agreement with those observed by Huang et al. (2009) and Lemaître et al. (2010) considering that the aerosol load is much lower in our cases. LW and SW values for the HR are anticorrelated, with the strongest heating in the SW occurring in the same layers where the LW cooling is stronger and the aerosol load is higher.

\section{Summary and conclusions}

Two mineral dust events affecting Europe that were detected by both CALIPSO and the EARLINET ground-based lidar sites of Granada and Bucharest are analyzed in order to examine the feasibility of retrieving 2-D mineral dust radiative effects using satellite data and the GAME radiative transfer model. The first dust event was a strong event affecting western Europe on 7 April 2011 (GR event), whilst the second corresponds to a weaker event that affected eastern Europe on 4 July 2012 (BU event).

The retrieval of radiative properties with GAME using an aerosol parameterization (the so-called DAT1) combining
CALIPSO vertical information with the AOD from MODIS and dust microphysical properties from AERONET is performed. A second aerosol parameterization from combined ground-based lidar and sun photometer data (DAT2), which is already well established in the literature, is also applied in the present study to the EARLINET sites of Granada and Bucharest for the retrieval of radiative property profiles. The aerosol direct radiative effects obtained with both parameterizations are intercompared for simultaneous and colocated CALIPSO and EARLINET lidar profiles in order to validate the DAT1, obtaining quite good agreement. Results indicate that the vertical distribution of the mineral dust provided by CALIPSO combined with MODIS AOD provides similar results to those obtained by the ground-based stations in spite of the higher noise in the CALIPSO lidar profiles.

Once the satellite-based methodology is validated, the 2-D DRE in both the SW and LW is calculated along CALIPSO tracks for both cases. In general terms, a strong correlation is observed between the absolute value of the DRE at the surface and MODIS AOD values, with correlation coefficients of -0.98 for GR and -0.70 for BU. Consequently, the DRE and HR are larger for GR, where the average AOD along the orbit is equal to 0.52 , which is much larger than the 0.16 value obtained for BU. DRE values at the surface reach up to $-169.8 \mathrm{~W} \mathrm{~m}^{-2}(\mathrm{SW})$ and $20 \mathrm{~W} \mathrm{~m}^{-2}(\mathrm{LW})$ in the GR case, and $-38.0 \mathrm{~W} \mathrm{~m}^{-2}(\mathrm{SW})$ and $4.0 \mathrm{~W} \mathrm{~m}^{-2}(\mathrm{LW})$ in the BU case, and are in good agreement with previous studies. As expected, the LW contribution shows the opposite behavior to the SW contribution and is much lower (less than $25 \%$ ). The effect of the LW counterweights the cooling in the SW range, and the respective averaged net DRE values 
at the BOA and TOA are -52.9 and $-33.5 \mathrm{~W} \mathrm{~m}^{-2}$ for GR and -12.4 and $-10.5 \mathrm{~W} \mathrm{~m}^{-2}$ for $\mathrm{BU}$, which translates to a decrease of the DRE of between $10 \%$ and $20 \%$ compared with the SW values. For the RE, the values obtained range between -80.3 and $-63.0 \mathrm{~W} \mathrm{~m}^{-2}$ for BU and -119.1 and $-79.3 \mathrm{~W} \mathrm{~m}^{-2}$ for GR at the BOA. Different values are obtained for both cases due to differences in the incoming radiation, dust properties and the surface albedo. The strong influence of the surface albedo on the SW radiative properties is evident in the GR case, where the shift from land to surface has a strong impact on the DRE and the RE values. Regarding the HR, LW and SW values are also anticorrelated, with positive values observed for the SW and negative values for the LW. A stronger effect is observed in those layers containing higher aerosol load (between 1 and $5 \mathrm{~km}$ for $\mathrm{GR}$ and below $4 \mathrm{~km}$ for $\mathrm{BU}$ ). The averaged profiles obtained at GR reach up to 0.72 and $0.07 \mathrm{Kd}^{-1}$ at $\mathrm{BU}$ for the $\mathrm{SW}$, whereas values for the $\mathrm{LW}$ are as low as $-0.18 \mathrm{~K} \mathrm{~d}^{-1}$ for GR and $-0.02 \mathrm{~K} \mathrm{~d}^{-1}$ for BU. Net HR values are $7 \%$ and $20 \%$ lower than the SW values for GR and BU, respectively.

The presented methodology based on satellite data allows us to extend the analysis of radiative properties with GAME from 1-D to 2-D by greatly increasing spatial and temporal coverage. In the present study, AERONET data are used to define the aerosol microphysical properties, which is currently not a limitation due to the large spatial extent of the network in regions such as Europe and North America. Nonetheless, the use of accurate microphysical properties from satellite data would greatly increase the use of this methodology without the need for ground-based instrumentation. Although this work is focused on the long-range transport of mineral dust, our methodology is easily applicable to the long-range transport of other aerosol types such as fire smoke or volcanic ash.

Data availability. Part of the data used in this publication were obtained as part of the AERONET and EARLINET networks and are publicly available. Data from MODIS and CALIPSO are available from the NASA website. For additional data or information please contact the authors.

Author contributions. MJGM, MS and NP designed the study and wrote the paper with contributions from all authors. MJGM, NP, $\mathrm{RB}, \mathrm{JABA}$ and DN provided data and performed data analysis. MJGM performed the model simulations with contributions from RB. All authors have given approval to the final version of the paper.

Competing interests. The authors declare that they have no conflict of interest.
Special issue statement. This article is part of the special issue "EARLINET aerosol profiling: contributions to atmospheric and climate research". It is not associated with a conference.

Acknowledgements. The authors would like to acknowledge the CALIPSO mission scientists and associated personnel and the MODIS team for the production of the data used in this research.

Financial support. This work was supported by the Juan de la Cierva-Formación program (grant no. FJCI-2015-23904); the European Union through the H2020 program (ACTRIS-2, grant no. 654109; ECARS, grant no. 602014; EUNADICS-AV, grant no. 723986); the Spanish Ministry of Economy and Competitiveness CE17 55 (project TEC2015-63832-P); the EFRD (European Fund for Regional Development); the Spanish Ministry of Science, Innovation and Universities (project CGL2017-90884-REDT); and the Unidad de Excelencia Maria de Maeztu (project MDM-20160600) financed by the Spanish Agencia Estatal de Investigación.

Review statement. This paper was edited by Eduardo Landulfo and reviewed by two anonymous referees.

\section{References}

Ansmann, A., Bösenberg, J., Chaikovsky, A., Comerón, A., Eckhardt, S., Eixmann, R., Freudenthaler, V., Ginoux, P., Komguem, L., Linné, H., Márquez, M. Á. L., Matthias, V., Mattis, I., Mitev, V., Müller, D., Music, S., Nickovic, S., Pelon, J., Sauvage, L., Sobolewsky, P., Srivastava, M. K., Stohl, A., Torres, O., Vaughan, G., Wandinger, U., and Wiegner, M.: Long-range transport of Saharan dust to northern Europe: The 11-16 October 2001 outbreak observed with EARLINET, J. Geophys. Res.-Atmos., 108, 4783, https://doi.org/10.1029/2003JD003757, 2003.

Balkanski, Y., Schulz, M., Claquin, T., and Guibert, S.: Reevaluation of Mineral aerosol radiative forcings suggests a better agreement with satellite and AERONET data, Atmos. Chem. Phys., 7, 81-95, https://doi.org/10.5194/acp-7-81-2007, 2007.

Barragan, R., Sicard, M., Totems, J., Léon, J. F., Dulac, F., Mallet, M., Pelon, J., Alados-Arboledas, L., Amodeo, A., Augustin, P., Boselli, A., Bravo-Aranda, J. A., Burlizzi, P., Chazette, P., Comerón, A., D’Amico, G., Dubuisson, P., GranadosMuñoz, M. J., Leto, G., Guerrero-Rascado, J. L., Madonna, F., Mona, L., Muñoz-Porcar, C., Pappalardo, G., Perrone, M. R., Pont, V., Rocadenbosch, F., Rodriguez-Gomez, A., Scollo, S., Spinelli, N., Titos, G., Wang, X., and Sanchez, R. $\mathrm{Z}$.: Spatio-temporal monitoring by ground-based and air- and space-borne lidars of a moderate Saharan dust event affecting southern Europe in June 2013 in the framework of the ADRIMED/ChArMEx campaign, Air Qual. Atmos. Heal., 10, 261-285, https://doi.org/10.1007/s11869-016-0447-7, 2017.

Bhawar, R. L., Lee, W.-S., and Rahul, P. R. C.: Aerosol types and radiative forcing estimates over East Asia, Atmos. Environ., 141, 532-541, https://doi.org/10.1016/J.ATMOSENV.2016.07.028, 2016. 
Binietoglou, I., Basart, S., Alados-Arboledas, L., Amiridis, V., Argyrouli, A., Baars, H., Baldasano, J. M., Balis, D., Belegante, L., Bravo-Aranda, J. A., Burlizzi, P., Carrasco, V., Chaikovsky, A., Comerón, A., D’Amico, G., Filioglou, M., Granados-Muñoz, M. J., Guerrero-Rascado, J. L., Ilic, L., Kokkalis, P., Maurizi, A., Mona, L., Monti, F., Muñoz-Porcar, C., Nicolae, D., Papayannis, A., Pappalardo, G., Pejanovic, G., Pereira, S. N., Perrone, M. R., Pietruczuk, A., Posyniak, M., Rocadenbosch, F., Rodríguez-Gómez, A., Sicard, M., Siomos, N., Szkop, A., Terradellas, E., Tsekeri, A., Vukovic, A., Wandinger, U., and Wagner, J.: A methodology for investigating dust model performance using synergistic EARLINET/AERONET dust concentration retrievals, Atmos. Meas. Tech., 8, 3577-3600, https://doi.org/10.5194/amt-8-3577-2015, 2015.

Claquin, T., Schulz, M., Balkanski, Y., and Boucher, O.: Uncertainties in assessing radiative forcing by mineral dust, Tellus B, 50, 491-505, https://doi.org/10.1034/j.1600-0889.1998.t01-200007.x, 1998.

Dee, D. P., Uppala, S. M., Simmons, A. J., Berrisford, P., Poli, P., Kobayashi, S., Andrae, U., Balmaseda, M. A., Balsamo, G., Bauer, P., Bechtold, P., Beljaars, A. C. M., van de Berg, L., Bidlot, J., Bormann, N., Delsol, C., Dragani, R., Fuentes, M., Geer, A. J., Haimberger, L., Healy, S. B., Hersbach, H., Hólm, E. V., Isaksen, L., Kållberg, P., Köhler, M., Matricardi, M., Mcnally, A. P., Monge-Sanz, B. M., Morcrette, J. J., Park, B. K., Peubey, C., de Rosnay, P., Tavolato, C., Thépaut, J. N., and Vitart, F.: The ERA-Interim reanalysis: Configuration and performance of the data assimilation system, Q. J. R. Meteorol. Soc., 137, 553-597, https://doi.org/10.1002/qj.828, 2011.

DeMott, P. J., Sassen, K., Poellot, M. R., Baumgardner, D., Rogers, D. C., Brooks, S. D., Prenni, A. J., and Kreidenweis, S. M.: African dust aerosols as atmospheric ice nuclei, Geophys. Res. Lett., 30, 1732, https://doi.org/10.1029/2003GL017410, 2003.

Di Biagio, C., di Sarra, A., Meloni, D., Monteleone, F., Piacentino, S., and Sferlazzo, D.: Measurements of Mediterranean aerosol radiative forcing and influence of the single scattering albedo, J. Geophys. Res., 114, D06211, https://doi.org/10.1029/2008JD011037, 2009.

di Sarra, A., Di Biagio, C., Meloni, D., Monteleone, F., Pace, G., Pugnaghi, S., and Sferlazzo, D.: Shortwave and longwave radiative effects of the intense Saharan dust event of 25-26 March 2010 at Lampedusa (Mediterranean Sea), J. Geophys. Res.Atmos., 116, D23209, https://doi.org/10.1029/2011JD016238, 2011.

Draxler, R. R. and Hess, G. D.: An Overview of the HYSPLIT_4 Modelling System for Trajectories, Dispersion, and Deposition, available at: http://citeseerx.ist.psu.edu/viewdoc/download?doi= 10.1.1.453.8780\&rep=rep1\&type $=$ pdf (last access: 20 March 2019), 1998.

Dubovik, O. and King, M. D.: A flexible inversion algorithm for retrieval of aerosol optical properties from Sun and sky radiance measurements, J. Geophys. Res.-Atmos., 105, 20673-20696, https://doi.org/10.1029/2000JD900282, 2000.

Dubovik, O., Sinyuk, A., Lapyonok, T., Holben, B. N., Mishchenko, M., Yang, P., Eck, T. F., Volten, H., Muñoz, O., Veihelmann, B., van der Zande, W. J., Leon, J. F., Sorokin, M., and Slutsker, I.: Application of spheroid models to account for aerosol particle nonsphericity in remote sensing of desert dust, J. Geophys. Res.-
Atmos., 111, D11208, https://doi.org/10.1029/2005JD006619, 2006.

Dubuisson, P., Dessailly, D., Vesperini, M., and Frouin, R.: Water vapor retrieval over ocean using near-infrared radiometry, J. Geophys. Res.-Atmos., 109, D19106, https://doi.org/10.1029/2004JD004516, 2004.

Dubuisson, P., Giraud, V., Chomette, O., Chepfer, H., and Pelon, J.: Fast radiative transfer modeling for infrared imaging radiometry, J. Quant. Spectrosc. Ra., 95, 201-220, https://doi.org/10.1016/j.jqsrt.2004.09.034, 2005.

Fernald, F. G.: Analysis of atmospheric lidar observations - Some comments, Appl. Optics, 23, 652-653, 1984.

Fernald, F. G., Herman, B. M., and Reagan, J. A.: Determination of aerosol height distributions by lidar, J. Appl. Meteorol., 11, 482-489, 1972.

Franke, K., Ansmann, A., Müller, D., Althausen, D., Wagner, F., and Scheele, R.: One-year observations of particle lidar ratio over the tropical Indian Ocean with Raman lidar, Geophys. Res. Lett., 28, 4559-4562, https://doi.org/10.1029/2001GL013671, 2001.

Gómez-Amo, J. L., Pinti, V., Di Iorio, T., di Sarra, A., Meloni, D., Becagli, S., Bellantone, V., Cacciani, M., Fuà, D., and Perrone, M. R.: The June 2007 Saharan dust event in the central Mediterranean: Observations and radiative effects in marine, urban, and sub-urban environments, Atmos. Environ., 45, 5385-5393, https://doi.org/10.1016/J.ATMOSENV.2011.06.045, 2011.

Granados-Muñoz, M. J., Bravo-Aranda, J. A., Baumgardner, D., Guerrero-Rascado, J. L., Pérez-Ramírez, D., Navas-Guzmán, F., Veselovskii, I., Lyamani, H., Valenzuela, A., Olmo, F. J., Titos, G., Andrey, J., Chaikovsky, A., Dubovik, O., Gil-Ojeda, M., and Alados-Arboledas, L.: A comparative study of aerosol microphysical properties retrieved from ground-based remote sensing and aircraft in situ measurements during a Saharan dust event, Atmos. Meas. Tech., 9, 1113-1133, https://doi.org/10.5194/amt9-1113-2016, 2016.

Granados-Muñoz, M. J., Sicard, M., Román, R., Benavent-Oltra, J. A., Barragán, R., Brogniez, G., Denjean, C., Mallet, M., Formenti, P., Torres, B., and Alados-Arboledas, L.: Impact of mineral dust on shortwave and longwave radiation: evaluation of different vertically resolved parameterizations in 1-D radiative transfer computations, Atmos. Chem. Phys., 19, 523-542, https://doi.org/10.5194/acp-19-523-2019, 2019.

Gupta, P., Remer, L. A., Levy, R. C., and Mattoo, S.: Validation of MODIS $3 \mathrm{~km}$ land aerosol optical depth from NASA's EOS Terra and Aqua missions, Atmos. Meas. Tech., 11, 3145-3159, https://doi.org/10.5194/amt-11-3145-2018, 2018.

Holben, B. N., Eck, T. F., Slutsker, I., Tanré, D., Buis, J. P., Setzer, A., Vermote, E., Reagan, J. A., Kaufman, Y. J., Nakajima, T., Lavenu, F., Jankowiak, I., and Smirnov, A.: AERONET - A federated instrument network and data archive for aerosol characterization, Remote Sens. Environ., 66, 1-16, https://doi.org/10.1016/S0034-4257(98)00031-5, 1998.

Huang, J., Fu, Q., Su, J., Tang, Q., Minnis, P., Hu, Y., Yi, Y., and Zhao, Q.: Taklimakan dust aerosol radiative heating derived from CALIPSO observations using the Fu-Liou radiation model with CERES constraints, Atmos. Chem. Phys., 9, 4011-4021, https://doi.org/10.5194/acp-9-4011-2009, 2009.

Kahn, R. A., Gaitley, B. J., Garay, M. J., Diner, D. J., Eck, T. F., Smirnov, A., and Holben, B. N.: Multiangle Imaging SpectroRadiometer global aerosol product assessment by comparison with 
the Aerosol Robotic Network, J. Geophys. Res.-Atmos., 115, D23209, https://doi.org/10.1029/2010JD014601, 2010.

Karydis, V. A., Kumar, P., Barahona, D., Sokolik, I. N., and Nenes, A.: On the effect of dust particles on global cloud condensation nuclei and cloud droplet number, J. Geophys. Res.-Atmos., 116, D23204, https://doi.org/10.1029/2011JD016283, 2011.

Kim, M.-H., Omar, A. H., Tackett, J. L., Vaughan, M. A., Winker, D. M., Trepte, C. R., Hu, Y., Liu, Z., Poole, L. R., Pitts, M. C., Kar, J., and Magill, B. E.: The CALIPSO version 4 automated aerosol classification and lidar ratio selection algorithm, Atmos. Meas. Tech., 11, 6107-6135, https://doi.org/10.5194/amt11-6107-2018, 2018.

Kleidman, R. G., Smirnov, A., Levy, R. C., Mattoo, S., and Tanre, D.: Evaluation and Wind Speed Dependence of MODIS Aerosol Retrievals Over Open Ocean, IEEE T. Geosci. Remote, 50, 429435, https://doi.org/10.1109/TGRS.2011.2162073, 2012.

Klett, J. D.: Stable analytical inversion solution for processing lidar returns, Appl. Optics, 20, 211-220, 1981.

Klett, J. D.: Lidar inversion with variable backscatter/extinction ratios, Appl. Optics, 24, 1638-1643, 1985.

Landulfo, E., Papayannis, A., Artaxo, P., Castanho, A. D. A., de Freitas, A. Z., Souza, R. F., Vieira Junior, N. D., Jorge, M. P. M. P., Sánchez-Ccoyllo, O. R., and Moreira, D. S.: Synergetic measurements of aerosols over São Paulo, Brazil using LIDAR, sunphotometer and satellite data during the dry season, Atmos. Chem. Phys., 3, 1523-1539, https://doi.org/10.5194/acp-3-15232003, 2003.

Lemaître, C., Flamant, C., Cuesta, J., Raut, J.-C., Chazette, P., Formenti, P., and Pelon, J.: Radiative heating rates profiles associated with a springtime case of Bodélé and Sudan dust transport over West Africa, Atmos. Chem. Phys., 10, 8131-8150, https://doi.org/10.5194/acp-10-8131-2010, 2010.

Levy, R. C., Remer, L. A., Martins, J. V., Kaufman, Y. J., PlanaFattori, A., Redemann, J., Wenny, B., Levy, R. C., Remer, L. A., Martins, J. V., Kaufman, Y. J., Plana-Fattori, A., Redemann, J., and Wenny, B.: Evaluation of the MODIS Aerosol Retrievals over Ocean and Land during CLAMS, J. Atmos. Sci., 62, 974992, https://doi.org/10.1175/JAS3391.1, 2005.

Levy, R. C., Remer, L. A., Kleidman, R. G., Mattoo, S., Ichoku, C., Kahn, R., and Eck, T. F.: Global evaluation of the Collection 5 MODIS dark-target aerosol products over land, Atmos. Chem. Phys., 10, 10399-10420, https://doi.org/10.5194/acp-10-103992010, 2010.

Liu, D., Wang, Z., Liu, Z., Winker, D., and Trepte, C.: A height resolved global view of dust aerosols from the first year CALIPSO lidar measurements, J. Geophys. Res.-Atmos., 113, D16214, https://doi.org/10.1029/2007JD009776, 2008.

Liu, Z., Kar, J., Zeng, S., Tackett, J., Vaughan, M., Avery, M., Pelon, J., Getzewich, B., Lee, K.-P., Magill, B., Omar, A., Lucker, P., Trepte, C., and Winker, D.: Discriminating between clouds and aerosols in the CALIOP version 4.1 data products, Atmos. Meas. Tech., 12, 703-734, https://doi.org/10.5194/amt-12-7032019, 2019.

Lolli, S., Alparone, L., Garzelli, A., and Vivone, G.: Haze Correction for Contrast-Based Multispectral Pansharpening, IEEE Geosci. Remote S., 14, 2255-2259, 2017a.

Lolli, S., Campbell, J. R., Lewis, J. R., Gu, Y., and Welton, E. J.: Technical note: Fu-Liou-Gu and Corti-Peter model performance evaluation for radiative retrievals from cirrus clouds, At- mos. Chem. Phys., 17, 7025-7034, https://doi.org/10.5194/acp17-7025-2017, 2017b.

Lolli, S., Madonna, F., Rosoldi, M., Campbell, J. R., Welton, E. J., Lewis, J. R., Gu, Y., and Pappalardo, G.: Impact of varying lidar measurement and data processing techniques in evaluating cirrus cloud and aerosol direct radiative effects, Atmos. Meas. Tech., 11, 1639-1651, https://doi.org/10.5194/amt11-1639-2018, 2018.

Mallet, M., Dulac, F., Formenti, P., Nabat, P., Sciare, J., Roberts, G., Pelon, J., Ancellet, G., Tanré, D., Parol, F., Denjean, C., Brogniez, G., di Sarra, A., Alados-Arboledas, L., Arndt, J., Auriol, F., Blarel, L., Bourrianne, T., Chazette, P., Chevaillier, S., Claeys, M., D’Anna, B., Derimian, Y., Desboeufs, K., Di Iorio, T., Doussin, J.-F., Durand, P., Féron, A., Freney, E., Gaimoz, C., Goloub, P., Gómez-Amo, J. L., Granados-Muñoz, M. J., Grand, N., Hamonou, E., Jankowiak, I., Jeannot, M., Léon, J.-F., Maillé, M., Mailler, S., Meloni, D., Menut, L., Momboisse, G., Nicolas, J., Podvin, T., Pont, V., Rea, G., Renard, J.-B., Roblou, L., Schepanski, K., Schwarzenboeck, A., Sellegri, K., Sicard, M., Solmon, F., Somot, S., Torres, B., Totems, J., Triquet, S., Verdier, N., Verwaerde, C., Waquet, F., Wenger, J., and Zapf, P.: Overview of the Chemistry-Aerosol Mediterranean Experiment/Aerosol Direct Radiative Forcing on the Mediterranean Climate (ChArMEx/ADRIMED) summer 2013 campaign, Atmos. Chem. Phys., 16, 455-504, https://doi.org/10.5194/acp-16455-2016, 2016.

Mamouri, R. E., Amiridis, V., Papayannis, A., Giannakaki, E., Tsaknakis, G., and Balis, D. S.: Validation of CALIPSO spaceborne-derived attenuated backscatter coefficient profiles using a ground-based lidar in Athens, Greece, Atmos. Meas. Tech., 2, 513-522, https://doi.org/10.5194/amt-2-513-2009, 2009.

Meloni, D., Junkermann, W., di Sarra, A., Cacciani, M., De Silvestri, L., Di Iorio, T., Estellés, V., Gómez-Amo, J. L., Pace, G., and Sferlazzo, D. M.: Altitude-resolved shortwave and longwave radiative effects of desert dust in the Mediterranean during the GAMARF campaign: Indications of a net daily cooling in the dust layer, J. Geophys. Res., 120, 3386-3407, https://doi.org/10.1002/2014JD022312, 2015.

Meloni, D., di Sarra, A., Brogniez, G., Denjean, C., De Silvestri, L., Di Iorio, T., Formenti, P., Gómez-Amo, J. L., Gröbner, J., Kouremeti, N., Liuzzi, G., Mallet, M., Pace, G., and Sferlazzo, D. M.: Determining the infrared radiative effects of Saharan dust: a radiative transfer modelling study based on vertically resolved measurements at Lampedusa, Atmos. Chem. Phys., 18, 43774401, https://doi.org/10.5194/acp-18-4377-2018, 2018.

Mona, L., Amodeo, A., Pandolfi, M., and Pappalardo, G.: Saharan dust intrusions in the Mediterranean area: Three years of Raman lidar measurements, J. Geophys. Res.-Atmos., 111, D16203, https://doi.org/10.1029/2005JD006569, 2006.

Mona, L., Pappalardo, G., Amodeo, A., D’Amico, G., Madonna, F., Boselli, A., Giunta, A., Russo, F., and Cuomo, V.: One year of CNR-IMAA multi-wavelength Raman lidar measurements in coincidence with CALIPSO overpasses: Level 1 products comparison, Atmos. Chem. Phys., 9, 7213-7228, https://doi.org/10.5194/acp-9-7213-2009, 2009.

Morman, S. A. and Plumlee, G. S.: Dust and Human Health, in Mineral Dust, Springer Netherlands, Dordrecht, the Netherlands, 385-409, 2014. 
Navas-Guzmán, F., Antonio Bravo-Aranda, J., Luis GuerreroRascado, J., José Granados-Muñoz, M., and Alados-Arboledas, L.: Statistical analysis of aerosol optical properties retrieved by Raman lidar over Southeastern Spain, Tellus B, 65, 21234, https://doi.org/10.3402/tellusb.v65i0.21234, 2013.

Oikawa, E., Nakajima, T., Inoue, T., and Winker, D., A study of the shortwave direct aerosol forcing using ESSP/CALIPSO observation and GCM simulation, J. Geophys. Res.-Atmos., 118, 3687-3708, https://doi.org/10.1002/jgrd.50227, 2013.

Oikawa, E., Nakajima, T., and Winker, D.: An evaluation of the shortwave direct aerosol radiative forcing using CALIOP and MODIS observations, J. Geophys. Res.-Atmos., 123, 12111233, https://doi.org/10.1002/2017JD027247, 2018.

Omar, A., Liu, Z., Vaughan, M., Thornhill, K., Kittaka, C., Ismail, S., Hu, Y., Chen, G., Powell, K., Winker, D., Trepte, C., Winstead, E., and Anderson, B.: Extinction-to-backscatter ratios of Saharan dust layers derived from in situ measurements and CALIPSO overflights during NAMMA, J. Geophys. Res.Atmos., 115, D24217, https://doi.org/10.1029/2010JD014223, 2010.

Papagiannopoulos, N., Mona, L., Alados-Arboledas, L., Amiridis, V., Baars, H., Binietoglou, I., Bortoli, D., D'Amico, G., Giunta, A., Guerrero-Rascado, J. L., Schwarz, A., Pereira, S., Spinelli, N., Wandinger, U., Wang, X., and Pappalardo, G.: CALIPSO climatological products: evaluation and suggestions from EARLINET, Atmos. Chem. Phys., 16, 2341-2357, https://doi.org/10.5194/acp-16-2341-2016, 2016.

Papayannis, A., Balis, D., Amiridis, V., Chourdakis, G., Tsaknakis, G., Zerefos, C., Castanho, A. D. A., Nickovic, S., Kazadzis, S., and Grabowski, J.: Measurements of Saharan dust aerosols over the Eastern Mediterranean using elastic backscatter-Raman lidar, spectrophotometric and satellite observations in the frame of the EARLINET project, Atmos. Chem. Phys., 5, 2065-2079, https://doi.org/10.5194/acp-5-2065-2005, 2005.

Papayannis, A., Amiridis, V., Mona, L., Tsaknakis, G., Balis, D., Bösenberg, J., Chaikovski, A., De Tomasi, F., Grigorov, I., Mattis, I., Mitev, V., Müller, D., Nickovic, S., Pérez, C., Pietruczuk, A., Pisani, G., Ravetta, F., Rizi, V., Sicard, M., Trickl, T., Wiegner, M., Gerding, M., Mamouri, R. E., D'Amico, G., and Pappalardo, G.: Systematic lidar observations of Saharan dust over Europe in the frame of EARLINET (2000-2002), J. Geophys. Res.-Atmos., 113, D10204, https://doi.org/10.1029/2007JD009028, 2008.

Pappalardo, G., Wandinger, U., Mona, L., Hiebsch, A., Mattis, I., Amodeo, A., Ansmann, A., Seifert, P., Linn??, H., Apituley, A., Arboledas, L. A., Balis, D., Chaikovsky, A., D’Amico, G., De Tomasi, F., Freudenthaler, V., Giannakaki, E., Giunta, A., Grigorov, I., Iarlori, M., Madonna, F., Mamouri, R. E., Nasti, L., Papayannis, A., Pietruczuk, A., Pujadas, M., Rizi, V., Rocadenbosch, F., Russo, F., Schnell, F., Spinelli, N., Wang, X., and Wiegner, M.: EARLINET correlative measurements for CALIPSO: First intercomparison results, J. Geophys. Res.Atmos., 115, D00H19, https://doi.org/10.1029/2009JD012147, 2010.

Pappalardo, G., Amodeo, A., Apituley, A., Comeron, A., Freudenthaler, V., Linné, H., Ansmann, A., Bösenberg, J., D’Amico, G., Mattis, I., Mona, L., Wandinger, U., Amiridis, V., AladosArboledas, L., Nicolae, D., and Wiegner, M.: EARLINET: towards an advanced sustainable European aerosol lidar network,
Atmos. Meas. Tech., 7, 2389-2409, https://doi.org/10.5194/amt7-2389-2014, 2014.

Pérez, C., Nickovic, S., Pejanovic, G., Baldasano, J. M., and Özsoy, E.: Interactive dust-radiation modeling: A step to improve weather forecasts, J. Geophys. Res., 111, D16206, https://doi.org/10.1029/2005JD006717, 2006.

Peris-Ferrús, C., Gómez-Amo, J. L., Marcos, C., FreileAranda, M. D., Utrillas, M. P., and Martínez-Lozano, J. A.: Heating rate profiles and radiative forcing due to a dust storm in the Western Mediterranean using satellite observations, Atmos. Environ., 160, 142-153, https://doi.org/10.1016/J.ATMOSENV.2017.04.023, 2017.

Perrone, M. R. and Bergamo, A.: Direct radiative forcing during Sahara dust intrusions at a site in the Central Mediterranean: Anthropogenic particle contribution, Atmos. Res., 101, 783-798, https://doi.org/10.1016/j.atmosres.2011.05.011, 2011.

Perrone, M. R., Tafuro, A. M., and Kinne, S.: Dust layer effects on the atmospheric radiative budget and heating rate profiles, Atmos. Environ., 59, 344-354, https://doi.org/10.1016/J.ATMOSENV.2012.06.012, 2012.

Prasad, A. K., Singh, S., Chauhan, S. S., Srivastava, M. K., Singh, R. P., and Singh, R.: Aerosol radiative forcing over the Indo-Gangetic plains during major dust storms, Atmos. Environ., 41, 6289-6301, https://doi.org/10.1016/J.ATMOSENV.2007.03.060, 2007.

Redemann, J., Zhang, Q., Schmid, B., Russell, P. B., Livingston, J. M., Jonsson, H., and Remer, L. A.: Assessment of MODISderived visible and near-IR aerosol optical properties and their spatial variability in the presence of mineral dust, Geophys. Res. Lett., 33, L18814, https://doi.org/10.1029/2006GL026626, 2006.

Redemann, J., Vaughan, M. A., Zhang, Q., Shinozuka, Y., Russell, P. B., Livingston, J. M., Kacenelenbogen, M., and Remer, L. A.: The comparison of MODIS-Aqua (C5) and CALIOP (V2 \& V3) aerosol optical depth, Atmos. Chem. Phys., 12, 3025-3043, https://doi.org/10.5194/acp-12-3025-2012, 2012.

Remer, L. A., Kaufman, Y. J., Tanré, D., Mattoo, S., Chu, D. A., Martins, J. V., Li, R.-R., Ichoku, C., Levy, R. C., Kleidman, R. G., Eck, T. F., Vermote, E., and Holben, B. N.: The MODIS Aerosol Algorithm, Products, and Validation, J. Atmos. Sci., 62, 947-973, https://doi.org/10.1175/JAS3385.1, 2005.

Remer, L. A., Mattoo, S., Levy, R. C., Heidinger, A., Pierce, R. B., and Chin, M.: Retrieving aerosol in a cloudy environment: aerosol product availability as a function of spatial resolution, Atmos. Meas. Tech., 5, 1823-1840, https://doi.org/10.5194/amt5-1823-2012, 2012.

Rogers, R. R., Vaughan, M. A., Hostetler, C. A., Burton, S. P., Ferrare, R. A., Young, S. A., Hair, J. W., Obland, M. D., Harper, D. B., Cook, A. L., and Winker, D. M.: Looking through the haze: evaluating the CALIPSO level 2 aerosol optical depth using airborne high spectral resolution lidar data, Atmos. Meas. Tech., 7, 4317-4340, https://doi.org/10.5194/amt-7-4317-2014, 2014.

Rosenfeld, D., Rudich, Y., and Lahav, R.: Desert dust suppressing precipitation: a possible desertification feedback loop, P. Natl. Acad. Sci. USA, 98, 5975-5980, https://doi.org/10.1073/pnas.101122798, 2001.

Schaaf, C. and Wang, Z.: MCD43C3 MODIS/Terra+Aqua BRDF/Albedo Albedo Daily L3 Global 0.05Deg CMG V006 [Data set]. NASA EOSDIS Land Processes DAAC, https://doi.org/10.5067/MODIS/MCD43C3.006, 2015. 
Schmid, B., Michalsky, J., Halthore, R., Beauharnois, M., Harrison, L., Livingston, J., Russell, P., Holben, B., Eck, T., and Smirnov, A.: Comparison of aerosol optical depth from four solar radiometers during the fall 1997 ARM intensive observation period, Geophys. Res. Lett., 26, 2725-2728, https://doi.org/10.1029/1999GL900513, 1999.

Sicard, M., Bertolín, S., Mallet, M., Dubuisson, P., and Comerón, A.: Estimation of mineral dust long-wave radiative forcing: sensitivity study to particle properties and application to real cases in the region of Barcelona, Atmos. Chem. Phys., 14, 9213-9231, https://doi.org/10.5194/acp-14-9213-2014, 2014a.

Sicard, M., Bertolín, S., Muñoz, C., Rodríguez, A., Rocadenbosch, F., and Comerõn, A.: Separation of aerosol fine- and coarsemode radiative properties: Effect on the mineral dust longwave, direct radiative forcing, Geophys. Res. Lett., 41, 6978-6985, https://doi.org/10.1002/2014GL060946, 2014b.

Sicard, M., Barragan, R., Dulac, F., Alados-Arboledas, L., and Mallet, M.: Aerosol optical, microphysical and radiative properties at regional background insular sites in the western Mediterranean, Atmos. Chem. Phys., 16, 12177-12203, https://doi.org/10.5194/acp-16-12177-2016, 2016 a.

Sicard, M., Barragan, R., Muñoz-Porcar, C., Comerón, A., Mallet, M., Dulac, F., Pelon, J., Alados Arboledas, L., Amodeo, A., Boselli, A., Bravo-Aranda, J. A., D'amico, G., Granados Muñoz, M. J., Leto, G., Guerrero Rascado, J. L., Madonna, F., Mona, L., Pappalardo, G., Perrone, M. R., Burlizzi, P., Rocadenbosch, F., Rodríguez-Gómez, A., Scollo, S., Spinelli, N., Titos, G., Wang, X., and Zanmar Sanchez, R.: Contribution of EARLINET/ACTRIS to the summer 2013 Special Observing Period of the ChArMEx project: monitoring of a Saharan dust event over the western and central Mediterranean, Int. J. Remote Sens., 37, 4698-4711, https://doi.org/10.1080/01431161.2016.1222102, 2016b.

Sokolik, I. N. and Toon, O. B.: Direct radiative forcing by anthropogenic airborne mineral aerosols, Nature, 381, 681-683, https://doi.org/10.1038/381681a0, 1996.

Stamnes, K., Tsay, S.-C., Wiscombe, W., and Jayaweera, K.: Numerically stable algorithm for discrete-ordinate-method radiative transfer in multiple scattering and emitting layered media, Appl. Optics, 27, 2502, https://doi.org/10.1364/AO.27.002502, 1988.

Tackett, J. L., Winker, D. M., Getzewich, B. J., Vaughan, M. A., Young, S. A., and Kar, J.: CALIPSO lidar level 3 aerosol profile product: version 3 algorithm design, Atmos. Meas. Tech., 11, 4129-4152, https://doi.org/10.5194/amt-11-4129-2018, 2018.

Vaughan, M. A., Powell, K. A., Winker, D. M., Hostetler, C. A., Kuehn, R. E., Hunt, W. H., Getzewich, B. J., Young, S. A., Liu, Z., McGill, M. J., Vaughan, M. A., Powell, K. A., Winker, D. M., Hostetler, C. A., Kuehn, R. E., Hunt, W. H., Getzewich, B. J., Young, S. A., Liu, Z., and McGill, M. J.: Fully Automated Detection of Cloud and Aerosol Layers in the CALIPSO Lidar Measurements, J. Atmos. Ocean. Tech., 26, 2034-2050, https://doi.org/10.1175/2009JTECHA1228.1, 2009.

Vaughan, M. A., Garnier, A., Tackett, J. L., Avery, M. A., Kar, J., Liu, Z., and Zeng, S.: Overview of the CALIPSO Version 4 Lidar dataproducts, 8th Symposium on Lidar Atmospheric Applications, 97th Annual Meeting, American Meteorological Society, 22-26 January 2017, Seattle, WA, USA, 2017.
Wandinger, U., Tesche, M., Seifert, P., Ansmann, A., Müller, D., and Althausen, D.: Size matters: Influence of multiple scattering on CALIPSO light-extinction profiling in desert dust, Geophys. Res. Lett., 37, L10801, https://doi.org/10.1029/2010GL042815, 2010.

Wang, H., Shi, G. U., Zhu, J., Chen, B., Che, H. Z., and Zhao, T. L.: Case study of longwave contribution to dust radiative effects over East Asia, Chinese Sci. Bull., 58, 3673-3681, https://doi.org/10.1007/s11434-013-5752-z, 2013.

Wielicki, B. A., Barkstrom, B. R., Harrison, E. F., Lee, R. B., Louis Smith, G., Cooper, J. E., Wielicki, B. A., Barkstrom, B. R., Harrison, E. F., III, R. B. L., Smith, G. L., and Cooper, J. E.: Clouds and the Earth's Radiant Energy System (CERES): An Earth Observing System Experiment, B. Am. Meteorol. Soc., 77, 853-868, https://doi.org/10.1175/15200477(1996)077<0853:CATERE>2.0.CO;2, 1996.

Wielicki, B. A., Barkstrom, B. R., Baum, B. A., Charlock, T. P., Green, R. N., Kratz, D. P., Lee, R. B., Minnis, P., Smith, G. L., Takmeng Wong, Young, D. F., Cess, R. D., Coakley, J. A., Crommelynck, D. A. H., Donner, L., Kandel, R., King, M. D., Miller, A. J., Ramanathan, V., Randall, D. A., Stowe, L. L., and Welch, R. M.: Clouds and the Earth's Radiant Energy System (CERES): algorithm overview, IEEE T. Geosci. Remote, 36, 1127-1141, https://doi.org/10.1109/36.701020, 1998.

Winker, D. M., Vaughan, M. A., Omar, A., Hu, Y., Powell, K. A., Liu, Z., Hunt, W. H., and Young, S. A.: Overview of the CALIPSO mission and CALIOP data processing algorithms, J. Atmos. Ocean. Tech., 26, 2310-2323, https://doi.org/10.1175/2009JTECHA1281.1, 2009.

Winker, D. M., Pelon, J., Coakley, J. A., Ackerman, S. A., Charlson, R. J., Colarco, P. R., Flamant, P., Fu, Q., Hoff, R. M., Kittaka, C., Kubar, T. L., Le Treut, H., Mccormick, M. P., Mégie, G., Poole, L., Powell, K., Trepte, C., Vaughan, M. A., and Wielicki, B. A.: The CALIPSO Mission, B. Am. Meteorol. Soc., 91, 1211-1230, https://doi.org/10.1175/2010BAMS3009.1, 2010.

Young, S. A., Vaughan, M. A., Kuehn, R. E., and Winker, D. M.: The Retrieval of Profiles of Particulate Extinction from Cloud-Aerosol Lidar and Infrared Pathfinder Satellite Observations (CALIPSO) Data: Uncertainty and Error Sensitivity Analyses, J. Atmos. Ocean. Techn., 30, 395-428, https://doi.org/10.1175/JTECH-D-12-00046.1, 2013.

Young, S. A., Vaughan, M. A., Garnier, A., Tackett, J. L., Lambeth, J. D., and Powell, K. A.: Extinction and optical depth retrievals for CALIPSO's Version 4 data release, Atmos. Meas. Tech., 11, 5701-5727, https://doi.org/10.5194/amt-11-5701-2018, 2018.

Zhu, A., Ramanathan, V., Li, F., and Kim, D.: Dust plumes over the Pacific, Indian, and Atlantic oceans: Climatology and radiative impact, J. Geophys. Res., 112, D16208, https://doi.org/10.1029/2007JD008427, 2007. 